\title{
CONRAD MARTENS, UN PAISAJISTA EN EL FIN DEL MUNDO. LAS IMÁGENES Y EL VIAJE DEL BEAGLE (1831-1836)
}

MARTA PENHOS

\section{RESUMEN}

Este artículo pone foco en la producción artística de Conrad Martens (1801-1878) en el marco de la segunda etapa del viaje del Beagle (1831-1836). Martens integró la expedición entre 1833 y 1834 durante uno de los relevamientos en Patagonia y Tierra del Fuego. Se parte de la premisa de que en los viajes y expediciones de la modernidad, especialmente de los siglos XVIII y XIX, las imágenes fueron factores decisivos de la construcción, transmisión y difusión de conocimientos científicos y elaboraciones artísticas sobre espacios no europeos y sus habitantes. El examen de las acuarelas y dibujos de Martens y de otras fuentes visuales y textuales se utiliza para poner a prueba la hipótesis de que la formación como paisajista del pintor entró en tensión con la observación de espacios con características alejadas de los modelos artísticos vigentes en Europa a principios del siglo XIX.

PALABRAS CLAVE: Martens, Beagle, imágenes, Tierra del Fuego.

\section{CONRAD MARTENS, A LANDSCAPE PAINTER AT THE END OF THE WORLD. IMAGES AND THE VOYAGE OF BEAGLE (1831-1836)}

\begin{abstract}
This article focuses on the artistic production of Conrad Martens (1801-1878) during the second stage of the Beagle's voyage (1831-1836). Martens was part of the expedition between 1833 and 1834 during one of the surveys in Patagonia and Tierra del Fuego. This work is based on the premise that images were important factors in the construction, transmission and dissemination of scientific knowledge and artistic elaborations about non-European spaces and their inhabitants in the journeys and expeditions of modernity, especially in the 18th and 19th centuries. The examination of the watercolors and drawings of Martens and other visual and textual sources is used to test the hypothesis that the painter's training as landscape painter was in tension with the observation of spaces with characteristics far from the current artistic models in Europe at the beginning of the 19th century.
\end{abstract}

KEY WORDS: Martens, Beagle, images, Tierra del Fuego.

Facultad de Filosofía y Letras, Universidad de Buenos Aires/Instituto de Investigaciones sobre Patrimonio Cultural, Universidad Nacional de San Martín (Argentina). m martapenhos@yahoo.com.ar 


\section{INTRODUCCIÓN}

Después de ingentes preparativos que llevaron meses, el 22 de mayo de 1826 el bergantín Beagle zarpó del puerto de Plymouth rumbo a Río de Janeiro, acompañado de un espacioso velero liviano, el Adventure. Así comenzó la primera etapa de la expedición que se conoce por el nombre de la nave que la encabezó ${ }^{1}$. Philip Parker King (1791-1856), a bordo del Adventure, tuvo el comando general, mientras que Pringle Stokes (1793-1828) fue el capitán del Beagle. El retorno a Inglaterra se verificó el 14 de octubre de 1830. En el segundo viaje, el Beagle partió hacia Sudamérica el 27 de diciembre de 1831 e iba bajo el mando de Robert Fitz Roy, y regresó el 2 de octubre de 1836.

El principal objetivo de la expedición, por lo menos en términos oficiales, fue la exploración hidrográfica de la Patagonia sur y Tierra del Fuego. Pero a pesar de las contribuciones sustantivas al conocimiento geográfico de la región que se derivaron de ella, el viaje del Beagle ha tenido una particular fortuna histórica. Hay que pensar, en primer lugar, en la coyuntura en la que se desarrolla, cuando a inicios del siglo XIX, fracasados los intentos de sometimiento de Buenos Aires por la vía militar, la corona británica desplegó otras modalidades de avance sobre territorios al sur del Río de la Plata. La Patagonia y las islas atlánticas se presentaban con indudables ventajas para el dominio estratégico y para la indagación científica, y en esos terrenos la expedición significó un avance importante para Gran Bretaña. En segundo lugar, sin duda le dio singular fama la participación en la segunda etapa de un Darwin joven y en los inicios de su carrera científica, ya que el propio naturalista la consideró la escuela en la que se completó su aprendizaje, se afianzó su vocación y se definieron sus intereses ${ }^{2}$.

No es ajena a la trascendencia de la expedición el secuestro, durante el primer viaje,

1 La expresión "viaje del Beagle" suele usarse para referir solo a la segunda etapa, ya que con ese nombre se popularizó el diario de Darwin, pero aquí se aplica a las dos etapas de lo que puede considerarse una única empresa.

2 Browne, 2007. La historia de El Origen de las Especies de Charles Darwin. Debate, Barcelona, pp. 29-42.

3 Al respecto ver Penhos y Baliña, 2018. "Y la nave va... de cuatro fueguinos, su estancia en Inglaterra, la muerte de uno de ellos, y la restitución de los otros tres a Tierra del Fuego en el segundo viaje. No era nueva la práctica de sustraer personas de su entorno para llevarlas a Europa con distintos propósitos. De hecho, en lo que se refiere a América, Colón fue el pionero de la práctica. Pero la experiencia sufrida por quienes los marinos llamaron Jemmy Button, Fuegia Basket, York Minster y Boat Memory dio lugar, como no ha sucedido en otros casos, a diferentes elaboraciones literarias y visuales en el siglo XX y en época contemporánea. Algunas de ellas retoman la versión de los hechos brindada por Fitz Roy, otras la reformulan en términos críticos, y algunas le dan a los fueguinos la voz que no se oye en las fuentes oficiales ${ }^{3}$.

Nos encontramos así con un caso con más de una arista que merece ser estudiada en profundidad. Este artículo aborda una de ellas: la producción artística de Conrad Martens (18011878) en el marco de la segunda etapa del viaje del Beagle (1831-1836), de la cual participó entre 1833 y 1834 durante uno de los relevamientos en Patagonia y Tierra del Fuego. Se parte de la premisa de que en los viajes y expediciones de la modernidad, especialmente de los siglos XVIII y XIX, las imágenes fueron factores decisivos de la construcción, transmisión y difusión de conocimientos científicos y versiones artísticas sobre espacios no europeos y sus habitantes.

El examen de las acuarelas y dibujos de Martens y de otras fuentes, visuales y textuales, se utiliza para poner a prueba la hipótesis de que la formación como paisajista del pintor entró en tensión con la observación de espacios con características alejadas de los modelos artísticos vigentes en Europa a principios del siglo XIX ${ }^{4}$.

La perspectiva se orienta a explorar las nociones de espacio y espacialidad en la percepción y representación de regiones extra-europeas por parte de viajeros y expedicionarios, manteniendo

Muchas historias para una historia, y algunas imágenes también". Capítulo VII del libro: Penhos, 2018. Paisaje con figuras. La invención de Tierra del Fuego a bordo del Beagle (1826-1836). Ampersand, Buenos Aires.

4 Lo que sigue retoma en forma resumida las principales líneas de análisis seguidas en Penhos, 2018, op. cit., en especial el capítulo V. 
cierta prudencia respecto de la agencia indígena, ya que para abordarla a menudo solo contamos con indicios fragmentarios y difíciles de interpretar. La mayor parte de estos indicios, además, se encuentra en los informes de viajes, de modo que el habla del margen, como lo llama De Certeau, el del salvaje, el loco, el niño, hasta la mujer, nos llega mediada por el amo, que la pone en orden ${ }^{5}$.

\section{LAS IMÁGENES Y EL VIAJE DEL BEAGLE}

Las imágenes fueron recursos muy valorados para documentar el conocimiento recogido durante las expediciones de los siglos XVIII y XIX. Si bien la autoridad de la palabra escrita conservó su primacía, diagramas, esquemas, someros perfiles de costa y esbozos de levantamientos cartográficos parciales ganaron terreno por su capacidad de compendiar, complementar, ordenar y dar a conocer información científica y técnica. Pero los mapas y las imágenes técnicas no estuvieron solos en esta tarea: también los dibujos y pinturas figurativos, realizados a partir de los lineamientos consagrados en las academias $y$ talleres europeos, fueron parte de verdaderas usinas iconográficas, como los viajes de Cook y Malaspina $^{6}$, por nombrar solo dos ejemplos del siglo XVIII. El viaje del Beagle no escapó a esta tendencia. Los apuntes de John Lort Stokes ${ }^{7}$ permiten asomarnos a la captación más o menos inmediata de lo observado, mediante anotaciones, diagramas y dibujos. Entre sus papeles, encontramos, distribuidos en una misma hoja, cálculos, costas delineadas esquemáticamente, y un pez que por algún motivo llamó la atención del marino. Pero la fuente principal donde aparecen seleccionados, elaborados y organizados los diarios, informes, borradores y otros escritos y las imágenes de diverso tipo que se gestaron

5 De Certeau, 2007. La invención de lo cotidiano. 1. Artes del hacer. Universidad Iberoamericana, México, pp. 170171.

6 Para el caso de Cook sigue siendo una referencia ineludible Smith y Joppien, 1985. The art of Captain Cook's voyages. Oxford University Press/Australian Academy of the Humanities, Melbourne, 2 vols.; para Malaspina, ver Penhos, 2005. Ver, conocer, dominar. Imágenes de Sudamérica a fines del siglo XVIII. Siglo XXI editores, Buenos Aires, Tercera parte.

7 Lort Stokes (1811-1885) fue guardiamarina en el primer durante la expedición es el texto oficial definitivo, Narrative of the Surveying Voyages of his Majesty's ships Adventure and Beagle... (en adelante Narrative...), publicado en 1839 en tres volúmenes y un apéndice ${ }^{8}$. Obra de autoría compleja donde encontramos diferentes voces y diferentes manos, a las que se suma la intervención clave del editor ${ }^{9}$, Narrative... permite indagar sobre el papel de las imágenes en el desarrollo de la expedición, y sobre la actuación de los artistas que tomaron parte de ella, en particular de Martens.

Además de la cartografía, presente en los dos mapas en pliegos sueltos que se encuentran en cada volumen, y en la lámina con la carta del río Santa Cruz en el segundo ${ }^{10}$, la edición de Narrative... incluyó, convenientemente elaborados, algunos dibujos técnicos: la sección imaginaria del canal Gabriel, para dar una idea general de los fondeaderos fueguinos y del efecto de las violentas tempestades que los azotan en la conformación distinta de ambas costas, y el plano de una de las angosturas del estrecho de Magallanes que muestra los singulares remolinos de sus aguas. Ambos fueron insertos en el texto del primer tomo ${ }^{11}$. El Apéndice al volumen II es más generoso en imágenes de esta clase: un plano con el relevamiento de parte de las costas fueguinas, tres láminas de mano de Fitz Roy que contienen cuatro dibujos cada una de tipos de nubes, y un esquema de mareas del océano Índico. Finalmente, el volumen III, Journal and Remarks de Darwin, contiene catorce imágenes dentro del texto, desde cabezas de pájaros hasta cortes transversales de arrecifes, pasando por dibujos de rocas y sencillos paisajes. Estas ilustraciones indican la centralidad que tenía para el naturalista la plasmación visual de sus observaciones, lo cual se advierte en la gran cantidad de esquemas y

viaje y teniente con funciones de hidrógrafo en el segundo. Narrative of the Surveying Voyages of his Majesty's ships Adventure and Beagle... in three volumes, London, Henry Colburn, 1839. Si bien se suele atribuir a King el primer tomo y a Fitz Roy el segundo, entiendo que la única autoría individual claramente expresada en la edición es la de Darwin para el tomo III.

9 Un estudio de la edición en Penhos, 2018, op. cit., cap. III.

10 Narrative..., Vol. II, entre pp. 338 y 339.

11 Narrative..., Vol. I, pp. 60 y 356. 
dibujos que se encuentran en los cuadernos de campo utilizados durante el viaje del Beagle $e^{12}$.

Pero los espacios fueguinos parecían necesitar otras imágenes. Los autores de Narrative... convocaron con insistencia un imaginario figurativo capaz de dar cuenta de aquello para lo cual los recursos de la palabra eran insuficientes. Es por ello que, en ambas etapas del viaje, varios integrantes de la expedición -entre ellos King, Fitz Roy, el guardiamarina Wilson, el teniente Wickham y Philip Gidley, el joven hijo de King que formó parte de la tripulación en ambos viajes- realizaron dibujos que sirvieron para la elaboración de algunos grabados de la edición ${ }^{13}$. Respecto de los grabadores, el editor convocó a un equipo entre cuyos integrantes al menos Thomas Landseer (1795-1880) era muy reconocido como pintor e ilustrador. Se trata de una verdadera maquinaria iconográfica que se pone en marcha durante el viaje, si bien en una escala más modesta, de acuerdo al modelo de Cook, en el cual textos e imágenes técnicas, cartográficas $y$ figurativas buscan conformar un dispositivo representacional comprensible y transmisible sobre las regiones exploradas. Y continúa funcionando más tarde, en la etapa de la edición, con la selección de imágenes originales para llevar a la estampa y su compaginación con los textos. Las Tablas 1 y 2 muestran los temas, autores y distribución de las láminas en Narrative...

A la hora de planificar el segundo viaje, y con relación a la necesidad de contar con imágenes figurativas, la colaboración de los oficiales no era suficiente. Al respecto, Fitz Roy explica al comienzo del volumen II:

Sabiendo bien que nadie activamente comprometido con los deberes del relevamiento en el que íbamos a ser empleados tendría tiempo -incluso si fuera hábil en ello- de hacer mucho uso del lápiz, contraté en forma privada a un artista, el señor Augustus Earle, aunque no sin la sanción del Almirantazgo, que le autorizó también a ser provisto de vituallas ${ }^{14}$.

Se trata del otro supernumerario que, en forma semejante a Darwin, fue sumado al segundo viaje por iniciativa de su comandante, y a quien iba a encargarse el registro visual de las peripecias del viaje. Ciencia y arte debían dar amplitud a la indagación enfocada en aspectos náuticos, para demostrar, con sus representaciones particulares pero hermanadas, que la expedición excedía los objetivos más pragmáticos e inmediatos en pos de encarar una aventura del conocimiento. Sigue relatando Fitz Roy:

Mr. Earle sufrió tanto por la continua mala salud, que no pudo seguir en el Beagle después de agosto de 1832. Pero vivió en Monte Video varios meses antes de su regreso a Inglaterra. La decepción causada por la pérdida de sus servicios fue disminuida por la llegada de Mr. Martens, a quien contraté para que embarcara conmigo como mi dibujante $e^{15}$.

El párrafo enfatiza la relación personal entre el marino y el artista, y muestra el papel preponderante que tenía en el proyecto de Fitz Roy la misión de poner en imágenes, con los recursos de la representación artística, las vistas descritas en el texto.

\section{DOS ARTISTAS PARA UN VIAJE}

Martens contaba con treinta y dos años cuando surgió la oportunidad de sumarse a la segunda etapa de la expedición, en octubre de 1833. Siguiendo el impulso de tantos artistas europeos que, por esos años, buscaban inspiración en regiones alejadas del mundo, se había embarcado en el Hyacinth para participar de un periplo de tres años que tenía como destino principal la India. Quiso el azar que, estando en Río de Janeiro, se enterara por Hamond, el antiguo

Chapman, era un camarada de Fitz Roy en un viaje anterior que se unió al Beagle en la segunda etapa. Ver Chapman, 2009. Darwin en Tierra del Fuego. Emecé, Buenos Aires, p. 31.

14 Narrative..., Vol. II, p. 19

15 Ibidem, p. 20. 
Tabla 1. Láminas Narrative... Vol. I.

\begin{tabular}{|c|c|c|c|}
\hline Lámina & Ubicación & Dibujante & Grabador \\
\hline Patagonian & Frontispicio & P. P. King & T. Landseer \\
\hline Montevideo & Frente a p. 1 & C. Martens & T. Landseer \\
\hline $\begin{array}{l}\text { Distant View of mount Sarmiento (with two } \\
\text { other views) }\end{array}$ & p. 26 & P. P. King & S. Bull \\
\hline $\begin{array}{l}\text { Curious Peak-Admiralty Sound (with other } \\
\text { views) }\end{array}$ & p. 52 & P. P. King & S. Bull \\
\hline Patagonian 'toldo' and tomb & p. 94 & P. P. King & T. Landseer \\
\hline Monte Video Mole & p. 105 & Aug. Earle & T. A. Prior \\
\hline Rio de Janeiro & p. 106 & Aug. Earle & P. Hair \\
\hline $\begin{array}{l}\text { Fuegians Wigwams at Hope Harbour, in the } \\
\text { Magdalen Channel }\end{array}$ & p. 126 & P. P. King & S. Bull \\
\hline Monte Video Custom-House & p. 187 & Aug. Earle & T. A. Prior \\
\hline Corcovado Mountain & p. 188 & Aug. Earle & S. Bull \\
\hline Mount Sarmiento & p. 252 & C. Martens & T. Landseer \\
\hline San Carlos de Chiloé & p. 275 & C. Martens & S. Bull \\
\hline Breast Ploughing in Chiloé & p. 287 & P. P. King & T. Landseer \\
\hline Point Arena-Chiloé (with other two views) & p. 300 & $\begin{array}{l}\text { Una de P. P. King, dos } \\
\text { de C. Martens }\end{array}$ & J. W. Cook \\
\hline $\begin{array}{l}\text { South West opening of Cockburn Channel } \\
\text { (with views of Headlands) }\end{array}$ & p. 407 & W. W. Wilson & S. Bull \\
\hline Wollaston Island, near Cape Horn & p. 433 & C. Martens & S. Bull \\
\hline $\begin{array}{l}\text { Chart of Part of South America, by Captain } \\
\text { P. P. King }\end{array}$ & p. 463 & P. P. King & \\
\hline
\end{tabular}

tripulante del Beagle, que Fitz Roy buscaba con urgencia reemplazar a Earle. La participación del artista duró un año, hasta noviembre de 1834, cuando Fitz Roy debió vender el Adventure en Valparaíso, y por lo tanto reducir la cantidad de personas en la dotación. Martens produjo más de cuatrocientas imágenes durante el viaje, la mayor

16 Keynes (Ed.), 1979. The Beagle Record. Selections from the original pictorial records and writen accounts of the voyage of H. M. S. Beagle, Cambridge University Press, Cambridge-Londres-Nueva York-Melbourne; Organ, 1996. Conrad Martens' Beagle Pictures. General Catalogue of the Drawings, Watercolours \& Oils executed by Conrad Martens in association with his voyages to South America \& the Pacific Islands whilst Artist with the Beagle Expedition on board vessels such as HMS Hyacinth, May 1833-9 February 1835. http://works.bepress.com/ morgan/41 [acceso: 10/4/2013].

17 Durante la investigación se estudiaron en forma directa parte acuarelas y dibujos a pluma y lápiz, entre las cuales unas doscientas cincuenta tienen por asunto la Patagonia, Tierra del Fuego y la costa sur del Pacífico americano ${ }^{16}$. Se conservan sueltas y en cuatro cuadernos de apuntes, de formato apaisado, que contienen dibujos a lápiz y algunos bocetos acuarelados, todos ellos plenos de anotaciones ${ }^{17}$.

las acuarelas PAF 6227-6242 del National Maritime Museum (Greenwich), y los Sketchbooks I y III, Cambridge University Library, Ms. Add. 7984. El conjunto de las obras de Martens se halla en colecciones públicas y privadas de Chile, Uruguay, Australia y Gran Bretaña. Los Sketchbooks II y IV se guardan en la colección R. Q. Macarthur Stanham, de Camden Park, Sydney. Es útil para estudiar la correspondencia entre los originales de Martens y los grabados de Narrative..., Organ, 1996, op. cit. Este autor consigna además un pequeño cuaderno con estudios de fueguinos y patagones, y del Río de la Plata, Montevideo y Puerto San Julián en la Dixson Library de Sydney. 
Tabla 2. Láminas Narrative... Vol. II.

\begin{tabular}{|c|c|c|c|}
\hline Lámina & Ubicación & Dibujante & Grabador \\
\hline Fuegian (Yapoo Tekeenica) & Frontispicio & C. Martens & T. Landseer \\
\hline Panoramic View of Madeira & Frente a p. 46 & $\begin{array}{l}\text { IGS } \\
\text { R. N. Hamond }\end{array}$ & S. Bull \\
\hline Crossing the Line & p. 57 & Aug. Earle & T. Landseer \\
\hline San Salvador, Bahia & p. 62 & Aug. Earle & T. A. Prior \\
\hline Patagonians at Gregory Bay & p. 136 & C. Martens & T. Landseer \\
\hline Fuegians & p. 141 & R. Fitz Roy & T. Landseer \\
\hline $\begin{array}{l}\text { Fuegians going to Trade in Zapallios } \\
\text { with Patagons }\end{array}$ & p. 171 & R. Fitz Roy & T. Landseer \\
\hline Woolya & p. 208 & R. Fitz Roy & T. Landseer \\
\hline Falklands & p. 248 & C. Martens & J. W. Cook \\
\hline Port Desire & p. 316 & C. Martens & S. Bull \\
\hline Button Island & p. 323 & C. Martens & T. Landseer \\
\hline Fuegians & p. 324 & R. Fitz Roy? & T. Landseer \\
\hline Cove in Beagle Channel & p. 336 & C. Martens & T. Landseer \\
\hline Beagle Laid Ashore & p. 339 & C. Martens & T. Landseer \\
\hline Basalt Glen & p. 348 & C. Martens & T. Landseer \\
\hline Santa Cruz & p. 351 & C. Martens & S. Bull \\
\hline Cordillera & p. 352 & C. Martens & S. Bull \\
\hline Mount Sarmiento & p. 359 & C. Martens & T. Landseer \\
\hline Valdivia & p. 398 & $\begin{array}{l}\text { Dos Fitz Roy, } \\
\text { una Philip Gidley King }\end{array}$ & T. Landseer \\
\hline Concepcion Catedral & p. 405 & Wickham & S. Bull \\
\hline Galápagos & p. 498 & P. G. King & S. Bull \\
\hline Tahiti & p. 509 & C. Martens & T. Landseer \\
\hline Tahiti & p. 517 & Dos Martens, una King & T. Landseer \\
\hline New Zealanders & p. 568 & $\begin{array}{l}\text { Fitz Roy } \\
\text { Earle }\end{array}$ & T. Landseer \\
\hline
\end{tabular}

Desafectado de la expedición en Valparaíso, el artista buscó el modo de volver a Inglaterra pero otra vez se le presentó la ocasión para seguir conociendo el mundo y partió en un barco que lo llevó a Tahití. De allí viajó a Nueva Zelanda, y finalmente a Sydney, donde llegó con una carta de recomendación de Fitz Roy a King quien, ya retirado de la Marina, se había afincado en la

18 Keynes, 1979, op. cit., pp. 2-5.

19 Gladstone Steele, 1978. Conrad Martens in Queensland: the frontier travels of a colonial artist. University of ciudad y lo ayudó a instalarse ${ }^{18}$. Relacionado con la élite de colonos británicos, Martens hizo una importante carrera; se convirtió así en el fundador de la llamada pintura colonial australiana. En general, las monografías y artículos que se le han dedicado trazan un puente entre sus años de formación en Inglaterra y la intensa actividad que desarrolló en Sydney ${ }^{19}$, y le otorgan menos espacio
Queensland Press, Brisbane; Bonyhady, 1991. Images in Opposition: Australian Landscape Painting, 1801-1890. Oxford University Press, Melbourne. 
y consideración a la etapa sudamericana ${ }^{20}$, que en ciertos autores aparece como una experiencia enriquecedora de aprendizaje previo a causa del contacto con geografías exóticas y personalidades estimulantes como Fitz Roy y Darwin ${ }^{21}$. Por ello resulta valioso un trabajo que se ha enfocado en la obra de Martens correspondiente a Chile, en particular la isla de Chiloé, puntualizando en los ambientes, paisajes, personajes y situaciones representados por el artista ${ }^{22}$.

Pero antes de seguir los pasos de Martens, debemos esbozar unas breves líneas sobre a quién Fitz Roy había elegido originalmente como dibujante. Augustus Earle (1793-1838) es un caso singular de artista itinerante. Cuando fue convocado para sumarse al Beagle era ya un avezado viajero: luego de estudiar con Benjamin West en Londres ${ }^{23}$, había hecho en forma independiente largos recorridos por los cinco continentes, que le posibilitaron, por ejemplo, una estancia en Australia y Nueva Zelanda entre 1825 y 1828. Alli hizo retratos, vistas panorámicas y escenas costumbristas $^{24}$. Pero además contaba en su haber con una experiencia "a lo Robinson Crusoe": ocho meses librado a su suerte en la isla Tristan da Cunha, en medio del Atlántico sur, de cuyos avatares dejó un vibrante testimonio en su diario. Es un texto de mucho interés, aunque se interrumpe justo cuando el artista se suma al Beagle $e^{25}$. Veamos qué dice el editor sobre la personalidad del dibujante, quien tuvo desde temprano amor por la errancia y las aventuras,

... como otros individuos que han resignado las comodidades y hasta la abundancia de la vida en sus países, para hacer descubrimientos en los campos de la ciencia, o para satisfacer un refinado

20 De Vries-Evans, 1993. Conrad Martens on the Beagle in Australia. Pandanus Press, Brisbane.

21 Organ, 1994. Conrad Martens: Journal of a Voyage from England to Australia aboard HMS Beagle and HMS Hyacinth 1833-35. State Library of New South Wales, Wollongong, pp. 7 y 16.

22 Van Meurs Valderrama, 2014. Conrad Martens en Chiloé, 1834. Ediciones Museo Regional de Ancud-Dirección de Bibliotecas, Archivos y Museos, Ancud.

23 Keynes, 1979, op. cit., p. 1.

24 Smith, 1985 [1960]. European Vision and South Pacific, 1768-1850. Yale University Press, New Haven, pp. 145- gusto por lo pintoresco; enfrentando climas nocivos, y los peligros que abundan en tierras salvajes, para adquirir conocimiento, e incrementar el conjunto de hechos a los que acuden tanto el estadista como el moralista ${ }^{26}$.

El párrafo es tan ajustado al programa romántico basado en el enlace entre política, ciencia y aventuras que no parece necesario comentar nada más. Escrito en una prosa ágil no exenta de información útil para emprendedores de todo tipo, el diario tuvo buena recepción, ya que a la promesa de un texto pleno de elementos atrayentes para el lector de la época se unía la fama que Earle había adquirido gracias a la exhibición en Londres de algunas de sus obras en forma de panorama. Según Browne, el libro se convirtió en una cause célèbre en su momento ${ }^{27}$.

Pese a estos antecedentes prometedores, ya a bordo del Beagle, Earle enfermó de reumatismo y no pudo producir muchas imágenes para la expedición. Los grabados de Narrative... que se hicieron a partir de sus dibujos son seis: "Montevideo Mole", "Rio de Janeiro", "Montevideo-CustomHouse" y "Corcovado Mountain" en el primer volumen, y "Crossing the Line" y "San Salvador, Bahia", además de las figuras que son parte de "New Zealanders", en el segundo. "Crossing the Line" es una animada escena con detalles sobre el rito de paso de la línea del ecuador, con mucha similitud en cuanto a composición y tratamiento con "Life on the Ocean" y "Divine Service on board a British frigate" 28 , dos óleos presentados en la Royal Academy en 1837 que muestran la vida a bordo del barco en el que Earle volvió a Inglaterra en 1820. También emparentada con estas vivaces representaciones está una acuarela que al parecer

153.

25 Earle, 1832. A Narrative of a Nine Months Residence in New Zealand in 1827. Longman \& Cia, Londres.

26 Ibidem, pp. iii-ix.

27 Browne, 1995. Charles Darwin. Voyaging. Princeton University Press, Princeton, p. 311

28 "Life on the Ocean Representing the usual Occupations of the Young Officers in the Steerage of a British Frigate at Sea" y "Divine Service as it is Usually Performed on Board a British Frigate at Sea (ca. 1820-1837)", National Maritime Museum, Greenwich. De la última obra hay otra versión en la National Library de Australia. 
representa una jornada en la cubierta del Beagle $e^{29}$. Gracias a las leyendas dentro de globos a la manera de una historieta sabemos que los personajes son Darwin, Fitz Roy y el cirujano Bynoe, además de marineros que tratan de hacer su trabajo obstaculizados por los fósiles que el primero subió a la nave.

En las vistas grabadas para Narrative... se comprueba la capacidad del dibujante para equilibrar, en una misma imagen, los elementos naturales, urbanos y arquitectónicos, y las figuras humanas. No se trata solo de una cuestión de proporciones, sino del balance entre la precisión de los detalles y el dinamismo de la composición, en la que se nos muestran pequeñas narraciones.

Fitz Roy no nos hace saber cómo dio con Earle, pero podemos pensar que la experiencia que éste había adquirido en sus derroteros personales fue suficiente carta de presentación. Más tarde, como se dijo, hubo de sustituirlo por Martens. Este era hijo de un comerciante que había llegado a Inglaterra como cónsul austríaco. Sus estudios artísticos nos llevan a Copley Fielding $(1787-1855)^{30}$, presidente de la Sociedad de Acuarelistas y uno de los más solicitados maestros de las primeras décadas del siglo XIX, quien lo orientó decididamente hacia el paisaje y las vistas topográficas. Fielding, figura preeminente en el panorama artístico británico de la época, tuvo activa participación en la Sociedad, creada a instancias de William Frederick Wells, un amigo de Joseph Mallord William Turner, a causa del tratamiento despectivo que recibía la joven generación de paisajistas por parte de la Royal Academy ${ }^{31}$. Autor también de óleos, Fielding obtuvo la mejor recepción de sus contemporáneos por sus obras a la acuarela. Un diccionario de artistas de 1866 nos brinda esta semblanza:

29 "Unique watercolour of Darwin on HMS Beagle tipped to fetch upwards of $£ 50,000$ at auction" salió en subasta en Sotheby's en diciembre de 2015, https://www.theguardian. com/books/2015/nov/25/rare-drawing-charles-darwinon-hms-beagle-50-thousand-sothebys-auction [acceso: 16/3/2016]. Mi gratitud a Peter Mason por haberme llamado la atención sobre esta imagen.

30 El padre del artista le dio el nombre de Antony Vandyck Copley Fielding en homenaje al pintor flamenco del siglo XVIII.

31 Hole (Ed.), 1922-1923. Masters of Water-Colour Painting. The Studio Ltd., Londres, p. 6.

32 Ottley, 1866. A Biographical and Critical Dictionary
Ningún artista supo mejor que $\mathrm{Mr}$. Fielding cómo pintar un paisaje lejano de una milla de ancho en un papel de pocas pulgadas, o cómo darle luz y aire a sus pinturas; $y$ no obstante cierta uniformidad de ejecución, la verdad y delicadeza de su pintura hicieron siempre bienvenidos sus trabajos. La peculiar dulzura y armonía que caracterizaron su estilo han atraido y gratificado el ojo tanto del artista como del espectador no iniciado ${ }^{32}$.

Muchas de las habilidades del maestro pasaron al discípulo, junto con la inclinación por la pintura al aire libre. Si bien Fielding no fue afecto a los grandes viajes, en su juventud realizó excursiones por Gales y Escocia, y también por sus espacios favoritos, los Downs del sur: según el diccionario, sus cuadros refieren a los ricamente arbolados paisajes de Yorkshire y a las cuestas amplias y cubiertas de rebaños de Sussex. Más tarde, ya trasladado a Brighton, encontró allî inspiración para pintar tormentas y naufragios, con tanto éxito como el apacible refugio de los ciervos en 'South Downs'33.

Observando algunas de las obras de Fielding de la época en que fue maestro de Martens ${ }^{34}$, podemos entender por qué incluso John Ruskin, que en su juventud había tomado clases con él, lo destacó en sus críticas y llegó a copiar la acuarela "Loch Achray"35. Fielding representa espacios naturales plenos de vegetación variada, con predominio de árboles altos y esbeltos que ocupan los lados de la composición, arroyuelos o lagunas, colinas o simples cuestas; espacios naturales, sí, pero hollados por el hombre, que hace su aparición en los pastores o viandantes, en

of Recent and Living Painters and Engravers. Forming a Supplement of Bryan's Dictionary of Painters and Engravers as edited by George Stanley. Bohm, Londres, p. 68 .

33 Idem.

34 La Tate Gallery de Londres posee una colección de obras de Fielding, ver por ejemplo: https://www.tate.org.uk/ art/artworks/fielding-loch-earn-with-ben-vorlich-t05473 y https://www.tate.org.uk/art/artworks/fielding-cader-idrisfrom-the-barmouth-sands-t00988

35 Hewison, 2000. Ruskin, Turner and the Pre-Raphaelites. Tate Gallery, Londres, pp. 18 y 47. 
los rebaños, en las casas o castillos ruinosos, en los puentecitos... Son notas del paisaje pintoresco, que el artista condimenta con la amplitud del encuadre, las generosas porciones de cielo sin interferencia de follajes, y los planos posteriores, a veces ocupados por montañas, en los cuales aplica una exagerada perspectiva atmosférica. A esto se agregan las figuras mínimas, detenidas en su paso para observar las lejanías, y cierta economía de elementos que da al paisaje un carácter despojado y agrega un tinte melancólico en el amable pintoresquismo tan del gusto victoriano, que aún hoy atrae en las casas de subastas.

A lo largo de su carrera, Fielding se afirmó en la búsqueda de efectos atmosféricos. A veces diáfano, a veces brumoso, a veces amenazando con tempestades, como en las escenas marítimas, el aire es uno de los protagonistas de sus pequeñas obras. Este pudo ser un punto importante en la valoración que le otorgó Ruskin, el paladín de Turner, si pensamos que abogaba por un arte que captase en forma directa la verdad de la naturaleza. Las nubes de muchos paisajes de Fielding están lejos de ser aquellas convencionales que otros pintores repetían de cuadro en cuadro, y que tanto disgustaban al crítico ${ }^{36}$. Sin embargo, con los años el paisajista se inclinó por adocenadas vistas a pleno sol, y por ello Ruskin cambió su parecer sobre él y le reprochó que complaciera así a sus clientes, cuando había dado muestras de poder pintar con éxito otros climas ${ }^{37}$.

Este es, entonces, el bagaje que Martens llevaba consigo al salir de Inglaterra. Es plausible que durante sus años de estudio en el taller de Fielding asistiera a la defensa del plain air y de la aprehensión visual de las cosas de la naturaleza, y se empapara de la exaltación del papel de la emoción y la imaginación en el arte. Según Organ, es imposible comprender la producción australiana de Martens fuera del contexto del "movimiento pintoresquista" que involucró a artistas, poetas e intelectuales británicos entre 1760 y $1830^{38}$. Antes del viaje, Martens probablemente tuvo conocimiento de las ideas de

36 Ibidem, p. 38.

37 De Vries-Evans, 1993, op. cit., p. 103.

38 Organ, 1993. Conrad Martens and the Picturesque: Precursor to Australian Impressionism, pp. 5-17, www. uow.edu.au/ morgan/graphics/cmpicturesque.pdf
William Gilpin -un ejemplar de su libro conocido como Wye Tour, de 1770, se encontraba en la biblioteca del artista en Sydney-, y alimentó su cultura visual con una multiplicidad de estímulos. Entre ellos podemos enumerar las obras de los acuarelistas del círculo de Fielding (De Wint, Cox, Prout), los cuadros de John Constable y de J. M. W. Turner, de quien reprodujo diseños del Liber Studiorum, las lecciones que había dejado Joshua Reynolds, y las imágenes de los héroes del pintoresquismo: Claude Lorrain, JeanBaptiste Poussin y los maestros holandeses del siglo XVII. Ya afincado en Sydney, poseedor de un taller al que acudian terratenientes locales en busca de vistas pastorales ${ }^{39}$, Martens desarrolló una pintura directamente vinculada con la doctrina pintoresquista, que no abandonó nunca, incluso cuando ésta, durante la década de 1840, empezó a caer bajo la crítica de Ruskin y los prerrafaelitas. Y no era por falta de actualización, ya que en una conferencia de 1856 demostró estar muy al tanto de estos desarrollos al citar textos de solo un año antes y pasajes de una biografía reciente de Constable y de Modern Painters I de Ruskin, de 1843. Más que a una desconexión con la metrópoli, su insistente cultivo del pintoresquismo -opina Organ- se debió al ejercicio de una técnica en la que había alcanzado gran solvencia y que era popular entre sus comitentes ${ }^{40}$.

\section{VER LA NATURALEZA CON LOS OJOS DEL ARTE}

Volvamos al momento en que el artista acababa de incorporarse al Beagle para iniciar su experiencia patagónica y fueguina. ¿Podía funcionar en esos parajes su premisa de que es solo por medio del arte que aprendemos a ver la naturaleza correctamente? ${ }^{41}$. ¿Cuánto de aquello que él había aprendido era útil para plasmar las peculiaridades de los espacios del sur de América? Por fortuna, además de realizar imágenes para la expedición, Martens -como otros artistas viajerosescribió un diario sobre su periplo de Inglaterra a

[acceso: 12/6/2012].

39 Bonyhady, 1991, op. cit., p. 50.

40 Organ, 1993, op. cit., p. 21.

41 Citado en Ibidem, p. 15. 
Australia incluido el paso por Sudamérica ${ }^{42}$, que nos permite asomarnos a sus vivencias en la etapa que nos interesa y confrontar sus imágenes y sus palabras sobre el sur del Sur.

Lo primero a notar es que, en forma semejante a Darwin, Martens quedó fascinado con los trópicos, y si bien su estancia en Río de Janeiro fue breve, produjo allí una buena cantidad de dibujos y acuarelas: ¡Qué lugar para un artista!, escribió en su diario el 5 de julio de 1833, apenas arribado a la ciudad carioca, y acudió al tópico de los límites de la palabra, que en este caso es superada por las posibilidades de la imagen: No intentaré hacer una descripción de este lugar; estoy realmente mal calificado para describir cualquier pensamiento, pero no para el paisaje, y por cierto soy más capaz con el lápiz que con la pluma ${ }^{43}$. El dibujante dedicó a Río los términos previsibles (hermoso, pintoresco), y realizó diez imágenes, casi todas vistas desde la costa.

El primer contraste con este despliegue de la naturaleza se produjo en Montevideo, cuyas inmediaciones le resultaron extremadamente poco interesantes ${ }^{44}$. Darwin y Martens establecieron desde el comienzo de la incorporación del segundo a la expedición una amistad que se sostendría por décadas, a pesar de radicarse luego a kilómetros de distancia uno del otro. Durante la experiencia del viaje debieron intercambiar las impresiones y sensaciones provocadas por los espacios sudamericanos, a partir de una base cultural en común que habilitó notables coincidencias en torno a la apreciación estética de estos paisajes. En una carta a su hermana Susan ${ }^{45}$, usando las alusiones visuales que son frecuentes en su prosa, el joven naturalista concede cierto atractivo a las planicies que rodean la capital uruguaya, por su libre amplitud, donde nada guía o limita tus pasos, pero enseguida dice que alli la imaginación no podría pintar nada más que aburrimiento $y$ falta de interés. Seguidamente, viene la inevitable comparación con la foresta de Brasil, que ofrece a cada minuto nuevos objetos a la admiración.

Es lógico que el espacio patagónico deparase a Martens mayores decepciones. Los alrededores

42 Organ, 1994, op. cit.

43 Ibidem, p. 16.

44 Ibidem, p. 18. de Puerto Deseado fueron para él un país estéril... [donde] hay poco para atraer o interesar al ojo. El párrafo que sigue es más que elocuente acerca de la intervención de las convenciones paisajísticas en aquello que Martens observaba:

Mejora un poco hacia la parte interior del puerto, donde el paisaje podría asemejarse un poco al de un hermoso lago, si no fuera deficiente en la más importante característica de la composición de lo bello, a saber: árboles, que de hecho rara vez son algo más que arbustos, y nunca sobrepasan la altura de un hombre ${ }^{46}$.

Faltando los árboles, la escena no podía enmarcarse, como era habitual en los cuadros de la época, y la mirada se perdía en un horizonte sin accidentes. Tal vez por ello el artista le dio total protagonismo al Beagle en una acuarela que hizo en su cuaderno el mismo día que escribió la entrada del diario. El barco domina el lado izquierdo de la imagen, al tiempo que la caracterización de un lugar tan falto de interés se deja a las costas rocosas, apenas interrumpidas por las pequeñas ruinas blancas del antiguo asentamiento español, al amplio cielo y al mar en calma.

Pese a esta percepción negativa, también en su cuaderno Martens ensayó una representación de las formaciones en el lado sur del puerto (Fig. 1), una acumulación de rocas [...] que se asemeja en una escala muy impresionante a uno de los tors de Dartmoor. El fenómeno le recordó algo ya visto, los afloramientos de piedra desnuda con los que terminan las colinas de Dartmoor, un páramo al sudoeste de Inglaterra, pero a una escala mayor como solo la geografía de América podía poner ante los ojos de los europeos, lo que le daba cierto atractivo. La página del cuaderno está ocupada, verticalmente, por tres planos sucesivos de formas irregulares, coloreadas por ocres y grises, en las que unos trazos torcidos y unas pocas manchas de color verde oscuro dan idea de la vegetación seca del lugar. Puerto Deseado no tenía más para ofrecer. Meses después, en marzo de 1834 y estando otra

45 Burkhardt (Ed.), 1996. The Beagle letters. Cambridge University Press, Cambridge, p. 139.

46 Organ, 1994, op. cit., p. 20. 
vez allí, Martens reitera en una carta a su hermano que hay poco para dibujar ${ }^{47}$, no obstante lo cual dejó no menos de veinte esquicios y pequeñas acuarelas sobre el sitio $^{48}$.

Ya en bahía San Gregorio, los patagones le merecen una descripción generalizadora -al principio no puede distinguir hombres de mujeres-, y no falta la referencia a su altura ${ }^{49}$; asimismo, les dedica algunos estudios a la acuarela bajo el título "Patagonians at Gregory Bay" 50 que sirvieron para las ilustraciones de Narrative...

El interés por el entorno se aviva después de pasar la segunda angostura del Estrecho, cuando en febrero de 1834 Martens anota:

El Sarmiento, el rey de las montañas de Tierra del Fuego, está a la vista, pero a una distancia de 90 millas; tiene 6.800 pies de altura, su apariencia es la de dos picos ásperos cubiertos de nieve. Se ven otras montañas de altura considerable y cubiertas en parte de nieve. Esto para mi es un gran placer, particularmente después de haber estado tanto tiempo en las costas chatas y estériles de la Patagonia ${ }^{51}$.

Por fin las elevaciones rompían la monotonía que había prevalecido hasta entonces, igual que las fogatas de los fueguinos, que a sus ojos eran objetos de considerable interés. Martens realizó varias acuarelas en las que domina el monte Sarmiento, las cuales fueron utilizadas para los grabados incluidos en la edición de Narrative... El rey de las montañas, según sus propias palabras, el más espléndido objeto de la naturaleza, como lo calificó el oficial Graves, el noble espectáculo

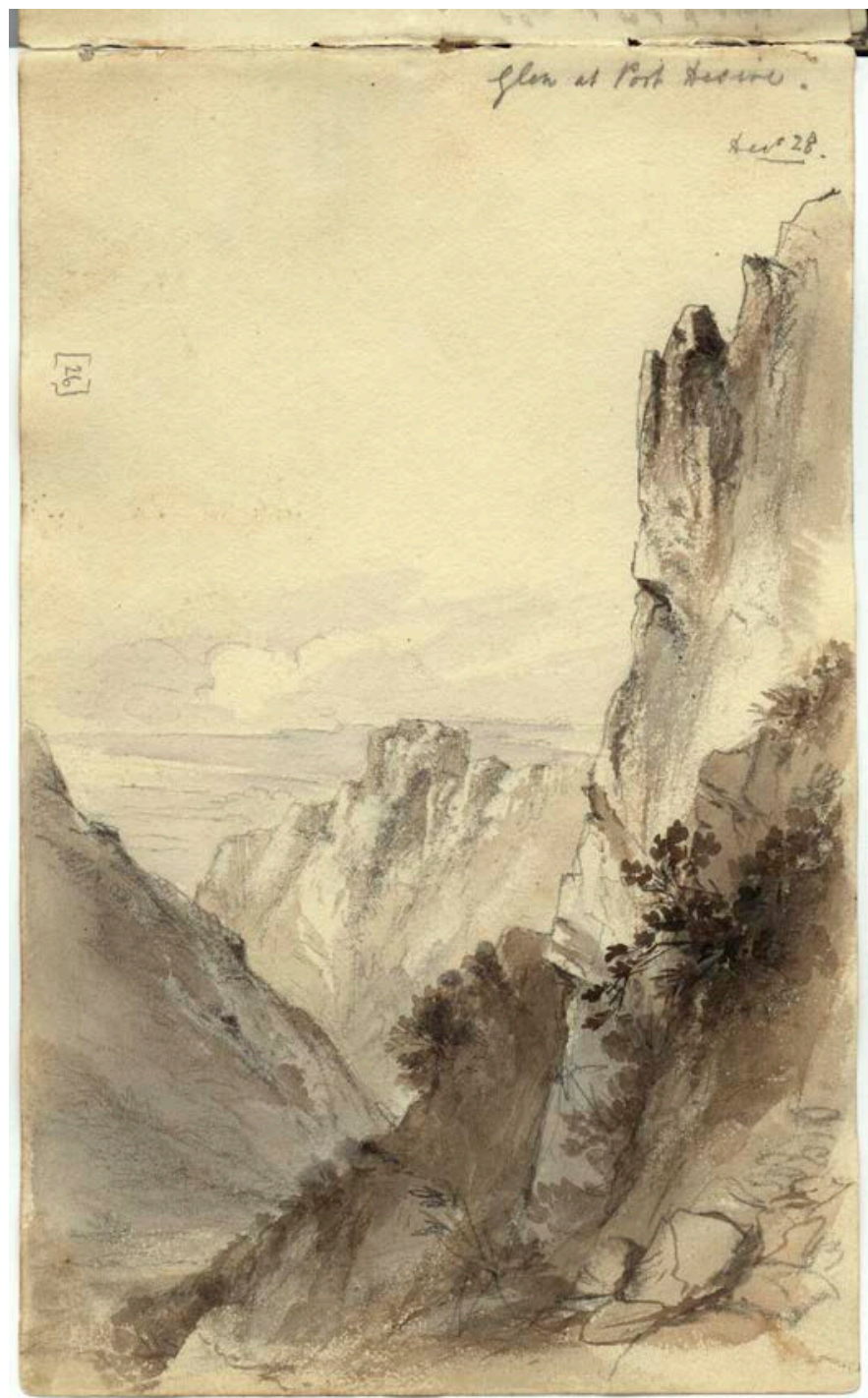

Fig. 1. Detalle de una hoja de los Manuscritos de John Lort Stokes (C) National Maritime Museum, Greenwich, STK/31, STK/63 y STK/69.

de Darwin, era sin duda un punto de atracción para alguien habituado a componer a partir de la concurrencia de una variedad de elementos naturales. El telón montañoso es uno de los recursos de Fielding en sus paisajes escoceses, que le da la ocasión de ensayar una estética de contrastes a partir de la luminosidad del fondo. De
47 Ibidem, p. 28.

48 Sería interesante una comparación entre los dibujos y acuarelas de Martens y la vista de Puerto Deseado de José del Pozo, realizada durante la Expedición Malaspina (1789-1794), sobre todo teniendo en cuenta la formación académica del sevillano y el cuño pintoresquista de Martens. Sobre del Pozo, ver Penhos, 2005, op. cit., cap. VI.

49 Organ, 1994, op. cit., p. 22.

50 Organ, 1996, op. cit., cat. 119, 123 y 124.

51 Organ, 1994, op. cit., p. 23. 
modo semejante, aunque con variaciones, Martens trabajó en las pinturas donde aparece el monte en base a la alternancia de planos de distinto valor. $\mathrm{Si}$ en los paisajes que incluyen el Sarmiento en el fondo, este es uniformemente claro y se abre a partir de los elementos oscuros de los primeros planos, en aquellas vistas más cercanas que lo tienen como protagonista se invierten los valores $y$ la masa blanca del Sarmiento se recorta contra un cielo más oscuro, rasgo que los grabados acentúan (Fig. 2) y que es compatible con la insistencia de King, Fitz Roy y los demás autores de Narrative... acerca de la escasez de jornadas en las que el aire fueguino era claro.

Detengámonos un poco en las acuarelas. Martens aplica, en general, capas muy livianas de color, mediante el uso de una paleta rica, clara y tonalizada. En "Mount Sarmiento, Tierra del Fuego, Showing Beagle" (Fig. 3) introduce azules plenos, apropiados para los hielos del glaciar que ocupan el centro de la composición, en contraste con las masas oscuras y cálidas de las formaciones rocosas. El Beagle, y esto es algo que se repite en varias de sus obras, es tratado con mucho detalle para permitir su rápida identificación. Detrás y a la derecha se ve la embarcación de rescate, que no compite en protagonismo con el bergantín.

Vale la pena transcribir el diario de Martens en su entrada del 9 de junio de 1834, cuando describe el canal Magdalena, ya que está plena de sugerencias respecto de los modos de ver del artista en esas latitudes:

Sus lados están mayormente revestidos de árboles, pero no muestran en general formas magníficas y picos como los del Canal Beagle, con la excepción sin embargo del Sarmiento, el Rey de Tierra del [Fuego], a lo largo de cuya base estábamos pasando ahora, aunque para mi gran decepción la niebla había aumentado y nada más que la parte inferior de los glaciares era visible. De estos tuvimos al mismo tiempo no menos de cuatro a la vista a poca distancia, y tenían un aspecto muy hermoso. Las partes niveladas, o solo suavemente inclinadas y cubiertas de nieve caída eran de un delicado color rosado, mientras que los riscos perpendiculares, de hielo puro y extremadamente tosco, aparecen en todos los tonos del azul más bello que hay, que pienso es peculiar de esa sustancia. Anclamos esta tarde en un pequeño y cómodo fondeadero, con las montañas elevadas abruptamente a la altura de 1.500 pies alrededor. Hubo un poco de relámpagos esta noche, la

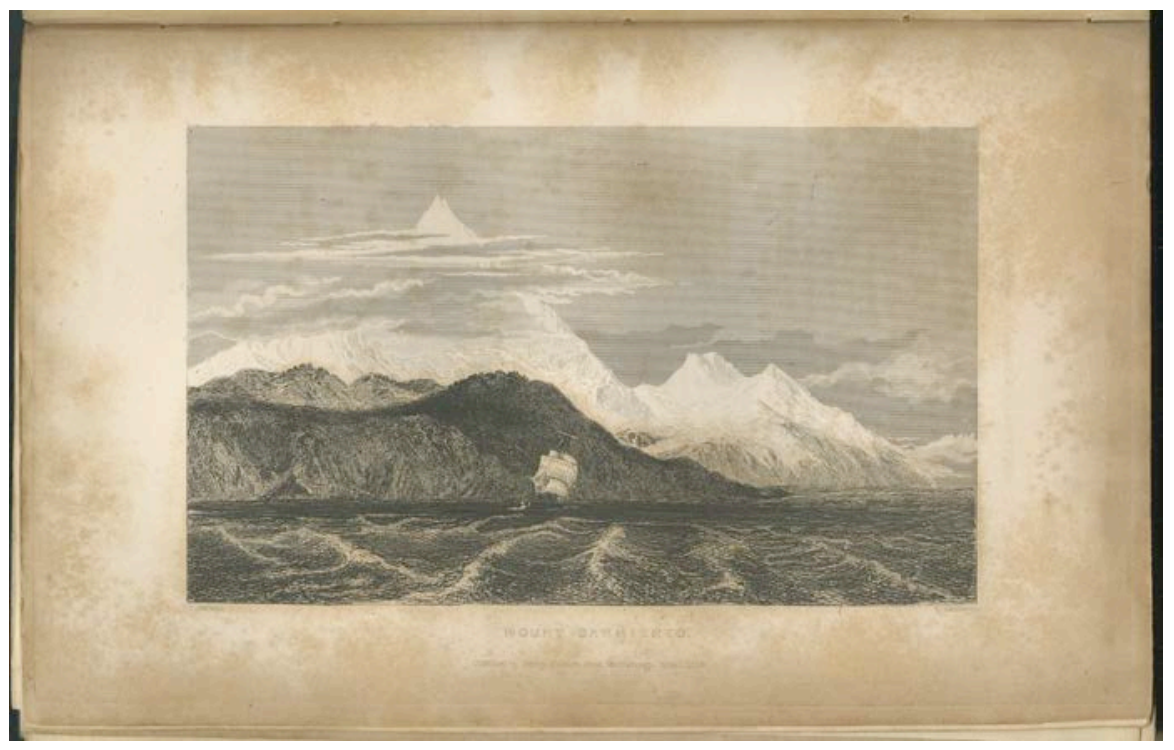

Fig. 2. Conrad Martens-Thomas Landseer, Mount Sarmiento, Narrative tomo I. Cortesía Biblioteca Nacional de la República Argentina. 


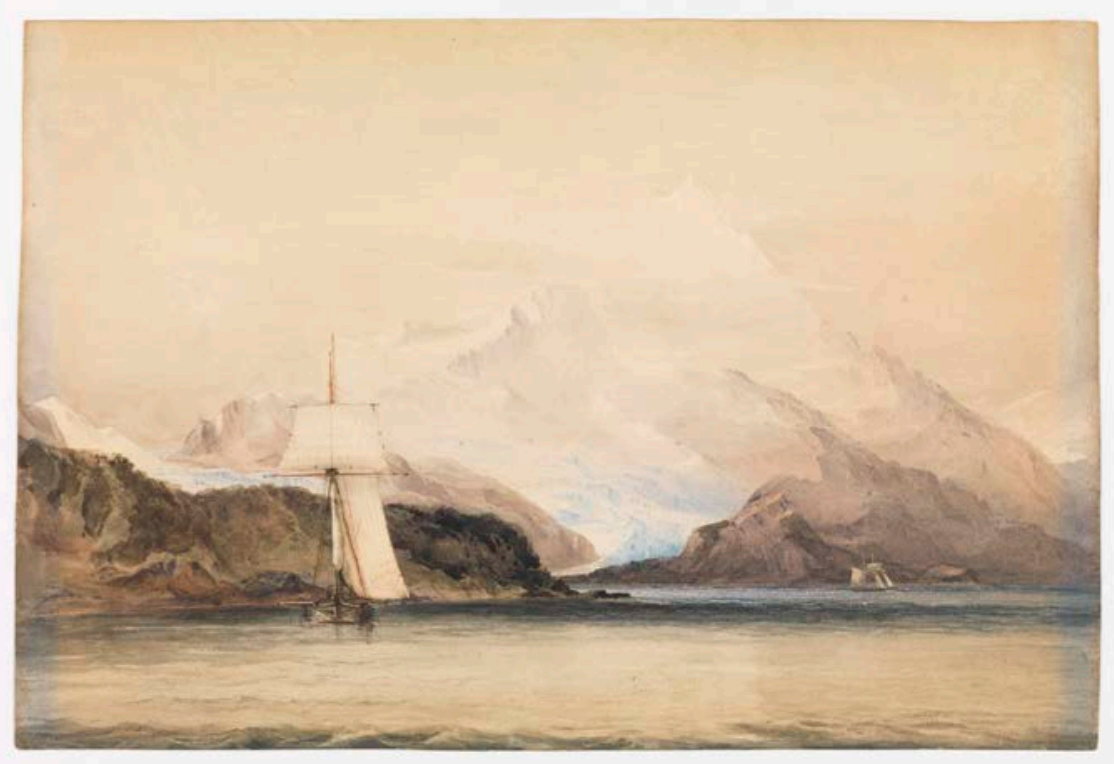

Fig. 3. Conrad Martens, Mount Sarmiento, Tierra del Fuego, Showing Beagle, PAF 6229. (C) National Maritime Museum, Greenwich.

primera que he visto en Terra [sic] del $\left[\right.$ Fuego ${ }^{52}$.

Como en un crescendo, al desinterés por el rústico canal, falto de formas atractivas, y a la decepción por el ocultamiento de la montaña a causa de la niebla, sigue el goce visual ante los colores delicados y bellos del glaciar, y la emoción provocada por la experiencia, no exenta de sublimidad, de la primera noche fueguina. Los colores les ganan a las formas, algo lógico viniendo de un artista con los antecedentes de Martens.

Es justamente a partir de algunos principios de la composición paisajística que el artista aborda una representación de Port Famine, en la cual se pone en evidencia otra vez el lugar central de las montañas en la construcción beagleana de los espacios fueguinos (Fig. 4). El artista abre una ventana enmarcada por dos árboles que, como paréntesis, ocupan los lados. Estos ejemplares y unos arbustos que compiten con la sequedad del suelo, tratados en base a manchas de verdes azulados mientras que los ocres dominan el resto, significan un atisbo de ese carácter vital que, según Darwin, estaba ausente del sitio: en estas

52 Ibidem, p. 37. inanimadas soledades, la Muerte, y no la Vida parecía el espíritu predominante ${ }^{53}$. La referencia al diario del naturalista es pertinente porque el título que Martens escribió en la hoja del cuaderno indica cuál es el motivo principal de la imagen, "Mont Tarn from the opposite side of Port Famine", que se ve en el fondo junto con otras montañas. Se trata de la elevación desde la cual Darwin observó un panorama de muerte. En definitiva, sus palabras y la pequeña acuarela de Martens representan miradas que convergen sobre un mismo espacio: ambas lo constituyen como paisaje, aunque al hacerlo le atribuyen notas diferentes.

El artista realizó una docena de imágenes sobre Puerto del Hambre y sus inmediaciones. Paralelamente a reducir lo percibido a los cánones de la pintura pintoresquista, parece haber sido sensible al sentido histórico del nombre del lugar, que transcribe en una larga leyenda dentro de una vista similar a la recién comentada, pero que tiene mayor amplitud gracias a la doble página del cuaderno:

Puerto del Hambre (visto a la izquierda) Bahía Lomas el más alto 2.963 la la

53 Narrative..., Vol. III, p. 233. 


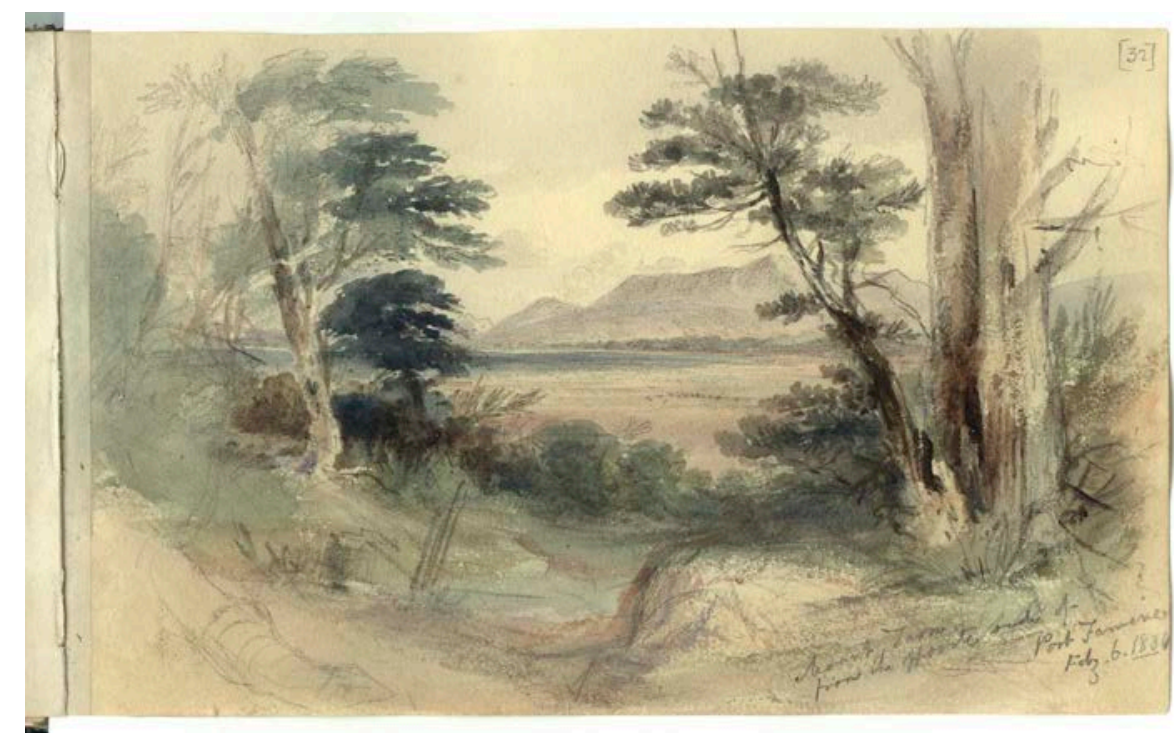

Fig. 4. Conrad Martens, Mount Tarn from the opposite side of Port Famine. Feby 6 1834, Sketchbook III. Cortesía Cambridge University Library.

derecha), monte Tarn 2700. Feb. 4 1834. Puerto del Hambre, asi llamado por Cavendish 1594, quien descubrió solamente 3 supervivientes de los cientos de colonos que embarcaron bajo Felipe II de España para fundar una colonia aquí - alrededor de 1580. Cap. Stokes, segundo comandante de la Expedición Británica, cometió suicidio aquí en 1826 como consecuencia de haber enfrentado durante 4 meses tormentas y corrientes en el estrecho de Magallanes tratando de pasar por él ${ }^{54}$.

La mención de Stokes y su trágico final, dejando de lado el error en la fecha, trae a su propia época la antigua historia de penurias que marcó la narrativa sobre Tierra del Fuego desde los inicios del siglo XVI ${ }^{55}$, que debió haber inquietado a Martens. En su diario, la puntual anotación de la temperatura y los comentarios de alivio cuando el clima es más benigno de lo que él esperaba indican que la experiencia en el sur de Sudamérica debió ser un desafío no solo respecto de su formación artística.

El monte Sarmiento es, sin duda, el rey de las representaciones fueguinas de Martens, quien

54 Organ, 1996, op. cit., cat. 126.

55 Al respecto, ver Penhos, 2018, op. cit., cap. II. le dedicó no menos de diez acuarelas y dibujos, además de un óleo que le encargó King en Sydney en $1838^{56}$. En muchas de estas imágenes, en forma similar al Tarn respecto de Puerto del Hambre, la elevación funciona como atractivo elemento que a la distancia equilibra con su magnificencia la austeridad del sitio desde el cual es observado. Es el caso de "Mnt Sarmiento 6800. Lomas Range, the highest 2963", una página del cuaderno III donde se impone el suelo seco y rocoso. A la izquierda, un pequeño árbol de follaje manchado, similar al de otras imágenes, es el único elemento que interrumpe la horizontalidad de la composición, junto con la nave estacionada en la bahía. En ese paisaje despojado, como parte del fondo, entre la cadena montañosa, se destaca el manto blanco y la doble cumbre del Sarmiento.

Una solución distinta, sin interferencia de otros elementos que no sean los de la naturaleza, se presenta en otra acuarela del mismo cuaderno que muestra al Sarmiento visto también desde Puerto del Hambre, pero a través del telescopio. Está enteramente dedicada al macizo, que esta vez se asoma clarísimo con sus dos picos y parte de su masa detrás de otras elevaciones resueltas como dos planos marrones violáceos, uno más oscuro

56 Organ, 1996, op. cit., cat. 257. 
que el otro. En el cielo, azul claro, apenas aparecen unas nubes alargadas. Aquí, aún más que en otras versiones, se omite el carácter fantasmagórico de la elevación, en el cual hacen hincapié los testimonios escritos, que describen el monte surgiendo entre nubes. En cambio, en los grabados, aun cuando se mantienen cerca de la imagen original de Martens, vemos las nubes atravesando los picos del Sarmiento, en forma similar al Chimborazo de Humboldt.

Martens introdujo, en las inscripciones que hizo en las páginas de sus sketchbooks, datos duros sobre los espacios y accidentes que transitaban y observaban los expedicionarios: medidas, distancias y ubicaciones, que ligan las imágenes con las tareas de relevamiento. Así, leemos en la mencionada vista del Sarmiento: Mount Sarmiento as seen from Port Famine by telescope, distant 49 miles. Feby 7 1834, y en otra semejante: Mount Sarmiento, from Port Famine, June 31834 - the mountain can be seen from this place in very clear weather, being distant 49 miles $^{57}$. Similar característica se observa en un segmento particular de su producción durante el viaje, una veintena de dibujos con siluetas de costa de la Patagonia y Tierra del Fuego ${ }^{58}$, que se sumaron a las demás imágenes técnicas realizadas por los oficiales de la expedición.

Pero las leyendas en sus cuadernos implican a veces una dimensión diferente que presenta tres facetas: repiten resumidamente partes del diario, entran en sintonía con descripciones hechas por otros beagleanos -en especial Darwin-, y aluden a una visualidad atravesada por premisas pictóricas. Veamos este ejemplo del cuaderno IV:

El gran glaciar, monte Sarmiento. La montaña alcanza una altura 3 veces mayor a la que se ve aquí, pero está en parte oculta por las nubes oscuras y la neblina -un débil brillo soleado ilumina la parte superior del glaciar, dando a su superficie nevada un tinte que parece casi rosado en contraste con el azul de sus masas de hielo- un arco iris suave y débil también era visible a la derecha del glaciar, pero por lo demás el conjunto era muy gris y sombrio [gloomy]. Junio $91834^{59}$.

La relación con la entrada del diario del mismo día es estrecha y en ambos textos los colores son los principales elementos que caracterizan la visualidad del artista:

La montaña [Sarmiento] está cubierta de nieve, a excepción de unos 1.500 pies de la base. Durante todo el día el cielo era de un gris claro y alguna parte de la montaña estaba por momentos oculta por pequeñas nubes horizontales de un gris más oscuro, por las cuales la escena se endurecía considerablemente. El color local de las montañas se compone generalmente de un marrón rojizo, verde, y púrpura, y a la distancia media es marrón rojizo, púrpura, y color de la pizarra. La púrpura oscura, con algunos toques de azul sirve para marcar los numerosos huecos y barrancos, mientras que aquellas partes que reciben la luz por lo general tienen color pizarra o ceniza, que armoniza bastante bien con las partes sombreadas de la nieve, pero el conjunto está sometido por la intervención de una atmósfera gris que es característica del paisaje de Terra [sic] del [Fuego ${ }^{60}$.

Martens escribe pintando y pinta a partir de modelos aprendidos, pero es evidente que fue especialmente sensible a ciertos rasgos peculiares de la geografía fueguina encarnados en el monte y sus glaciares, que de hecho eran fenómenos que él había deseado llevar a la imagen, según palabras suyas que Fitz Roy reproduce en una carta a Darwin $^{61}$. En este sentido, la página del Journal de Darwin correspondiente al mismo día transmite con mayor despliegue literario impresiones similares:

En la mañana fuimos deleitados por la vista de la niebla que gradualmente se levantaba y ponía al Sarmiento ante nuestros ojos. Esta montaña, que es una de las más altas de Tierra del Fuego,
57 Ibidem, cat. 249.

58 Ibidem, cat. 269-287.

59 Ibidem, cat. 255.
60 Organ, 1994, op. cit., p. 37.

61 Citado en Keynes, 1979, op. cit., p. 159. 
tiene 6.800 pies. Su base está vestida de árboles polvorientos, y por sobre estos se extiende un manto de nieve hasta la cumbre. Estas gruesas capas, que no se derriten nunca, y parecen destinadas a permanecer mientras el mundo exista, presentan un noble y hasta sublime espectáculo. La línea de la montaña es admirablemente clara y definida. Debido a la abundancia de luz reflejada en la blanca y brillante superficie, casi no se proyectan sombras en ninguna parte... Varios glaciares descienden por un curso tortuoso desde la nieve hasta la costa; pueden ser comparados con grandes Niágaras congelados, y quizás estas cataratas de hielo azul son más cabalmente hermosas que las de agua en movimiento ${ }^{62}$.

Aparece la recurrencia a los colores que observamos en Martens, lo que avala la idea de una visualidad compartida en torno a un imaginario paisajístico en boga en la época.

Martens, como otros pintores viajeros, hizo puntillosas anotaciones en los dibujos a lápiz de sus cuadernos, como una simple vía de retener aquello que estaba ante sus ojos o bien para completar los someros trazos con indicaciones de la paleta que aplicaría en una elaboración posterior. Una imagen del Sarmiento en el cuaderno IV lleva la siguiente leyenda: El cielo en general de un gris compuesto de azul [...], y no más oscuro que lo necesario para destacar la nieve. El agua es a veces de un bello azul, y en la pendiente de la orilla no se observa cambio de color. Junio $10^{63}$. Más brevemente consigna en un esquicio del cuaderno I sobre el río Santa Cruz: mañana gris con luz amarillenta sobre las montañas. Si estas palabras están ligadas a la observación, otras escritas junto a las diferentes partes del dibujo se encuentran en relación con el proceso de plasmación de lo observado, como es el caso de otro boceto de la zona del mismo río donde Martens precisa: rocas gris oscuro / la parte más alta marrón amarillento / con arbustos de un verde pálido.

62 Narrative..., Vol. III, p. 306.

63 Organ, 1996, op. cit., cat. 263.

\section{UN RÍO DE ORILLAS ESTÉRILES Y LA PROMESA DE LA CORDILLERA}

Pese a la apreciación poco entusiasta de los alrededores del río Santa Cruz, el artista registró varias de sus vistas. Seguramente incidió en ello su participación en una excursión que remontó su curso desde mediados de abril hasta principios de mayo de 1834, integrada por Fitz Roy, Darwin y un puñado de oficiales y marineros. Fue la oportunidad de identificar mínimas variantes en un panorama que, en general, se presentaba a los ojos de los británicos como desolado. Respecto del puerto, dice en su diario mediante el uso de la metáfora marítima tan presente en las descripciones decimonónicas de la pampa:

... posee todo el carácter de las costas patagónicas, a un lado con un suelo bajo de arena aparentemente sin fin, presenta a la vista un horizonte apenas distinguible del mar mismo, y al otro, acantilados arenosos de no mucha altura en cuyas laderas se dispersan algunos pequeños y escasos arbustos atrofiados mezclados con mechones de hierba seca gruesa, sobre los cuales solo el guanaco y el avestruz son capaces de existir ${ }^{64}$.

Luego comenta la decisión de Fitz Roy de explorar el río. Ya iniciado el recorrido, pasan varias jornadas sin que el entorno motive a Martens, que declara en la entrada del 25 de abril: hasta ahora no he hecho ni un solo dibujo. Al día siguiente, son otra vez las montañas las encargadas de brindar variedad al paisaje: la tierra a lo lejos, de considerable altura, se hizo ahora visible, y para mi gran satisfacción, de apariencia más irregular $y$ montañosa ${ }^{65}$. Fue el momento en que el artista comenzó a producir una sucesión de vistas que siguen muy de cerca las descripciones del diario. De hecho, en su mayor parte, están fechadas -del 26 de abril al 9 de mayo-, lo que facilita hacer la correlación palabra-imagen. Martens se sintió muy impresionado por la falta de límites de la planicie que se extendía a ambas orillas de la corriente. Por ello dibujó varios panoramas en dos o más

64 Organ, 1994, op. cit., p. 30.

65 Ibidem, p. 32. 
páginas de sus cuadernos, a partir del recurso de la adición de imágenes parciales, propio de las vistas topográficas desde el siglo XVII y utilizado en las expediciones político-científicas del XVIII. En el XIX, el medio y la técnica fotográficos brindarían a los viajeros nuevas posibilidades para construir este tipo de imagen ${ }^{66}$.

Respecto de las indicaciones de color, uno de estos dibujos a doble página de la tarde del 3 de mayo contiene varias leyendas junto a diferentes partes: verde amarronado..., amarillo muy claro con motas oscuras, suelo color arena con arbustos de un marrón verdoso claro. No conforme con esto, Martens aplicó una fina capa de aguada celeste en el agua y en los rápidos. En su diario consignó: El paisaje era ahora, como puede suponerse con facilidad, mucho más interesante aunque tan estéril como siempre, y confieso que yo estaba menos inclinado a volver ahora que algunos días antes. Pero el invierno se acercaba y la partida debía iniciar el regreso a la costa del mar, de modo que era necesario dejar a un lado la ilusión de acercarse a la cordillera, que los expedicionarios vieron a la distancia. El dibujante se consoló con la opinión de que el río era estéril en su fuente igual [que en su desembocadura y su curso] ${ }^{67}$.

El conjunto de imágenes del río Santa Cruz nos permite ahondar un poco más en la modalidad de trabajo de Martens. En efecto, en el pasaje de las rápidas líneas que captan más o menos directamente las formas de esos espacios austeros, a las acuarelas, y de ellas a los grabados para ilustrar Narrative... es posible comprobar diferentes procedimientos plásticos, y además mostrar pliegues en la relación ver-representar. Hay que aclarar que, contrariamente a las estampas de otros viajes que idealizan las imágenes hechas in situ -como sucede con Cook $^{68}$ y Malaspina- ${ }^{69}$, las láminas respetan en gran medida los originales, $y$ solo presentan variaciones menores que muchas veces son atribuibles a la técnica litográfica.

Pero volvamos al Santa Cruz. Un entorno que el dibujante caracterizó como falto de interés y

66 Penhos, 2005, op. cit., Tercera parte; Penhos, 2016. Las fotografías del Álbum de Encina, Moreno y Cía. (1883) y la construcción de la Patagonia como espacio geográfico y paisaje. Huellas, búsquedas en Arte y Diseño, 9, pp. 64-80.

67 Organ, 1994, op. cit., p. 34.

68 Greppi, 2005. 'On the Spot': Traveling Artists and the monótono en exceso era un verdadero reto a sus dotes de paisajista, y parece haberlo obligado a un ejercicio más documental que artístico, aunque esto no signifique la ausencia total de operaciones para dotar a las imágenes de cierto atractivo. Martens tomó como base el boceto a doble página recién comentado para componer una pintura de formato apaisado (Fig. 5) que pretende retener algo de la percepción de un amplio panorama. Respetó el planteo general e incluyó todos los elementos, escasos como es de esperar, que forman parte de la imagen original. El horizonte, algo bajo, se dilata hacia los lados, donde unos macizos en un plano medio lo interrumpen. Prevalecen los ocres y marrones, que dan idea de esa tierra estéril de las descripciones del diario, solo habitada por arbustos chatos, cuyas hojitas son apenas manchas transparentes, y restos de ramas secas y torcidas, simples trazos de pincel. En la lejanía, la cordillera, resuelta en matices de blancos y azules violáceos contra un cielo claro, de aire puro y saludable $e^{70}$, semeja un espejismo como aquellos que durante la travesía surgieron, según Fitz Roy, sobre una extensa llanura pedregosa, entre dos curvas del río y atormentaron a los expedicionarios ${ }^{71}$.

La desolación es total, y el grabado correspondiente no hace más que ahondar en el tono triste que, pese a la claridad de la paleta usada por Martens, domina la acuarela. En efecto, Bull, el grabador responsable de la ilustración (Fig. 6), tal vez deseoso de dar más variedad a la pobre vegetación de la acuarela, llenó el primer plano, muy oscuro, de arbustos y ramas.

La necesidad de habitar el desierto y de dar cuenta de la presencia británica en él habría animado a Bull y/o al editor de Narrative... a introducir en otra litografía de la obra (Fig. 7) los tres botes con los cuales la partida hizo la exploración, que en la acuarela de base se insinúan en trazos esquemáticos. Pero además adicionó otro elemento que Martens había comentado en el diario, no sin señalar su carácter ominoso: La soledad de la escena, en extremo salvaje, era acentuada

Iconographic Inventory of the World 1769-1859. En Driver y Martins (Eds.). Tropical Visions in the Age of Empire. University of Chicago Press, Chicago, pp. 23 y 42, p. 27.

69 Penhos, 2005, op. cit., pp. 318-321.

70 Organ, 1994, op. cit., p. 34

71 Narrative..., Vol. II, p. 349. 


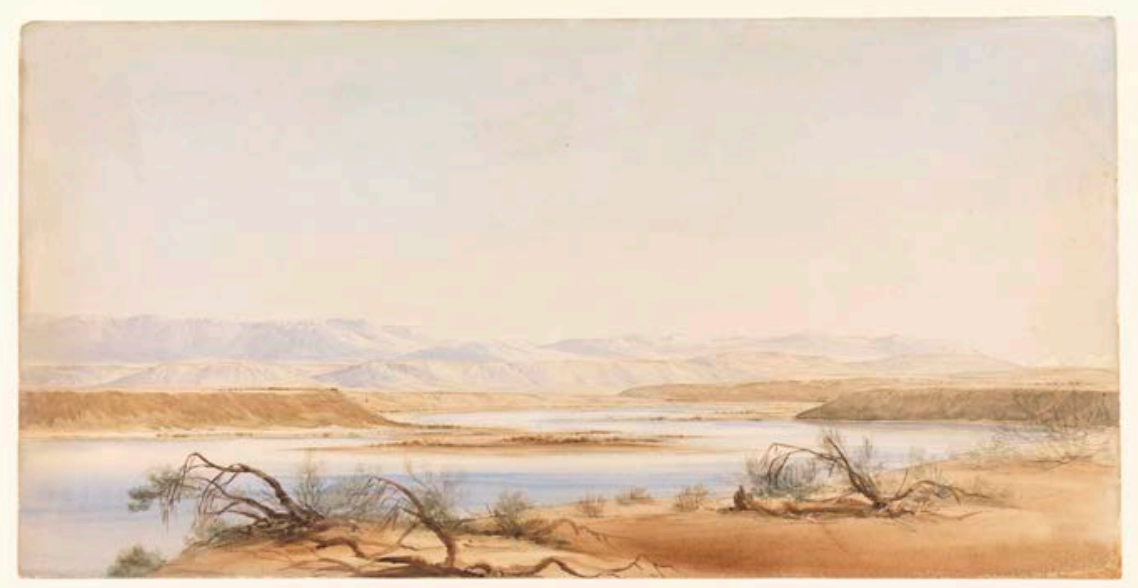

Fig. 5. Conrad Martens, Cordillera of the Andes from the Santa Cruz River, PAF 6233. (C) National Maritime Museum, Greenwich.

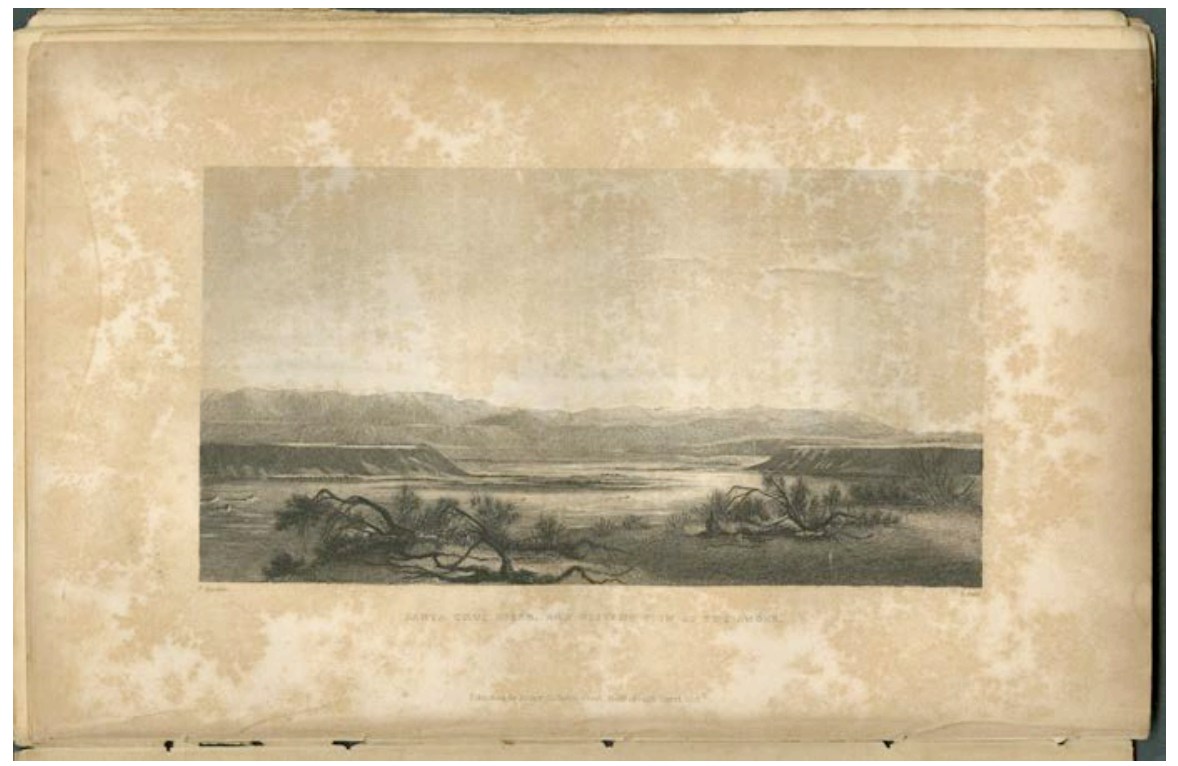

Fig. 6. Conrad Martens-S. Bull, Santa Cruz River, and distant view of the Andes, Narrative tomo II. Cortesía Biblioteca Nacional de la República Argentina.

por los montículos de huesos [de guanaco], que encontrábamos continuamente ${ }^{72}$. Los huesos, que aparecen en la lámina abajo a la izquierda, tienen una larga historia en la iconografía occidental como signo de muerte, y junto con el drástico contraste entre el plano cercano al espectador y el fondo, contribuyen a acentuar la polaridad entre la llanura árida e inanimada y la promesa de la lejana cordillera, de luminosas y variadas formas.
Veamos qué otros espacios reclamaron la atención de nuestro artista y pusieron a prueba su oficio de paisajista.

\section{PAISAJE CON FIGURAS}

Las representaciones de Tierra del Fuego realizadas por Martens, en su mayor parte, son vistas desde el mar o hacia el mar desde la orilla, sin 


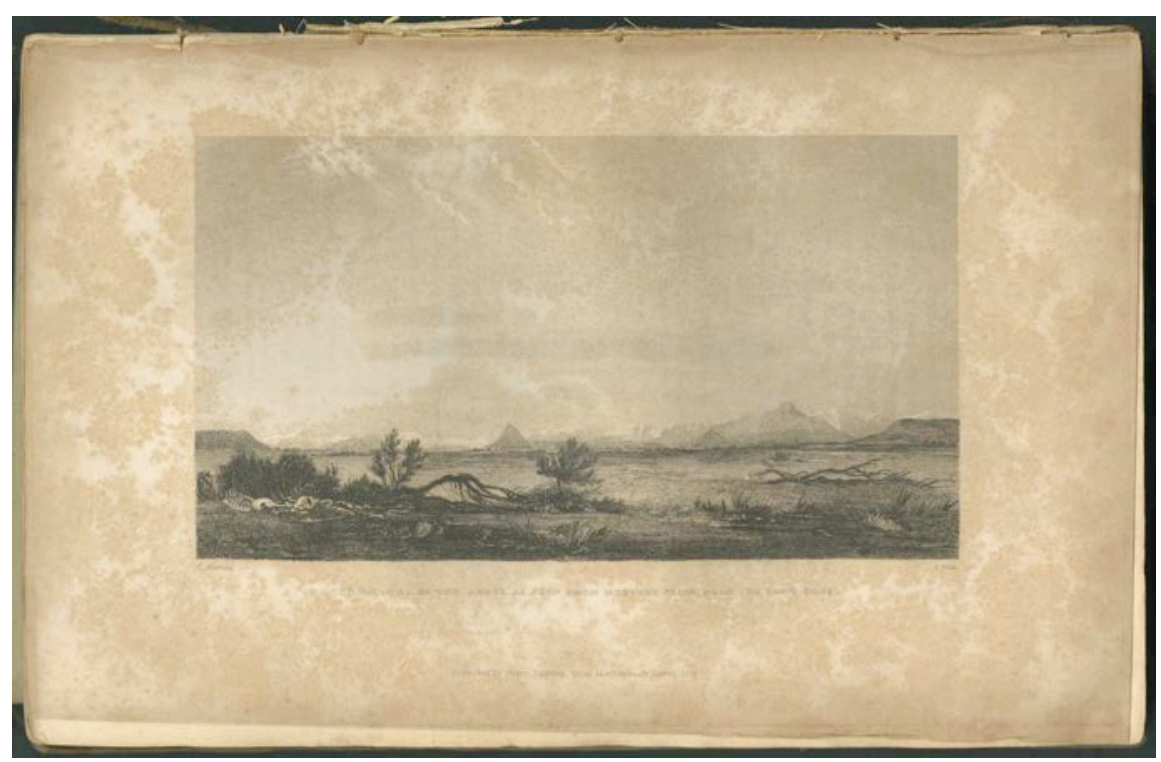

Fig. 7. Conrad Martens-S. Bull, Cordillera of the Andes, as seen from Mystery Plain, near the Santa Cruz, Narrative tomo II. Cortesía Biblioteca Nacional de la República Argentina.

que parezca que el artista haya tenido ocasión de estudiar el aspecto interior de la geografía fueguina, ni en la zona del canal ni en la del Estrecho. De hecho, no hay pistas en el diario de que haya participado de esas excursiones que tanto atraían a Darwin y que le hubieran posibilitado acceder a una vista desde lo alto. Curiosamente, los panoramas, representados por escrito con frecuencia por los autores de Narrative..., están ausentes en la producción beagleana del artista, quien sí realizó ese tipo de imagen más tarde en Sydney.

Dada la importancia del canal Beagle, descubierto y explorado durante el primer viaje, y de Wulaia, el sitio elegido para el asentamiento de los rehenes Jemmy, Fuegia y York, que ahora eran repatriados, es natural que Martens se haya abocado a la representación de estos parajes. Resulta llamativo que el relato de la trabajosa llegada de la nave al fondeadero, a finales de marzo de 1834, comience en el diario del dibujante con observaciones sobre los fueguinos que, en sus canoas, intentaban aproximarse a ella a pesar del vendaval. Dueños de muy pocas cosas, estas no podrían ser deseadas ni siquiera por el

73 Ibidem, pp. 25-26.

74 Ibidem, p. 25.

75 Es posible que, además, Martens haya aplicado en partes de sus obras el llamado body-colour o color opaco, que se coleccionista de curiosidades más conspicuo, afirma Martens, y apunta así a la escasez material que hacía a los habitantes de Tierra del Fuego tan poco atrayentes como su entorno en el que vivían $^{73}$.

La presencia de los indígenas, permanente durante la estancia de los expedicionarios en la zona del canal, provoca en el dibujante un juicio negativo sobre ellos, muy próximo al de Darwin: son los más desprovistos de los seres humanos ${ }^{74}$. Los representó de acuerdo con dos variantes: integrados en los paisajes o a través de estudios de figuras individuales. Un ejemplo servirá para ilustrar la primera. "Portrait Cove" (Fig. 8) muestra cinco fueguinos en la costa este de la isla Navarino, en el momento en que están descendiendo de su canoa. El artista delinea las figuras de un modo muy somero, pero logra atribuirles primitivismo con unos pocos recursos: distintos grados de desnudez, piel muy oscura, cabeza embutida en el torso. Como dije anteriormente, Martens trabajaba habitualmente con finas capas de color, pero a veces hay en sus obras diferencia de carga matérica, en este caso más espesa en los personajes ${ }^{75}$, y 


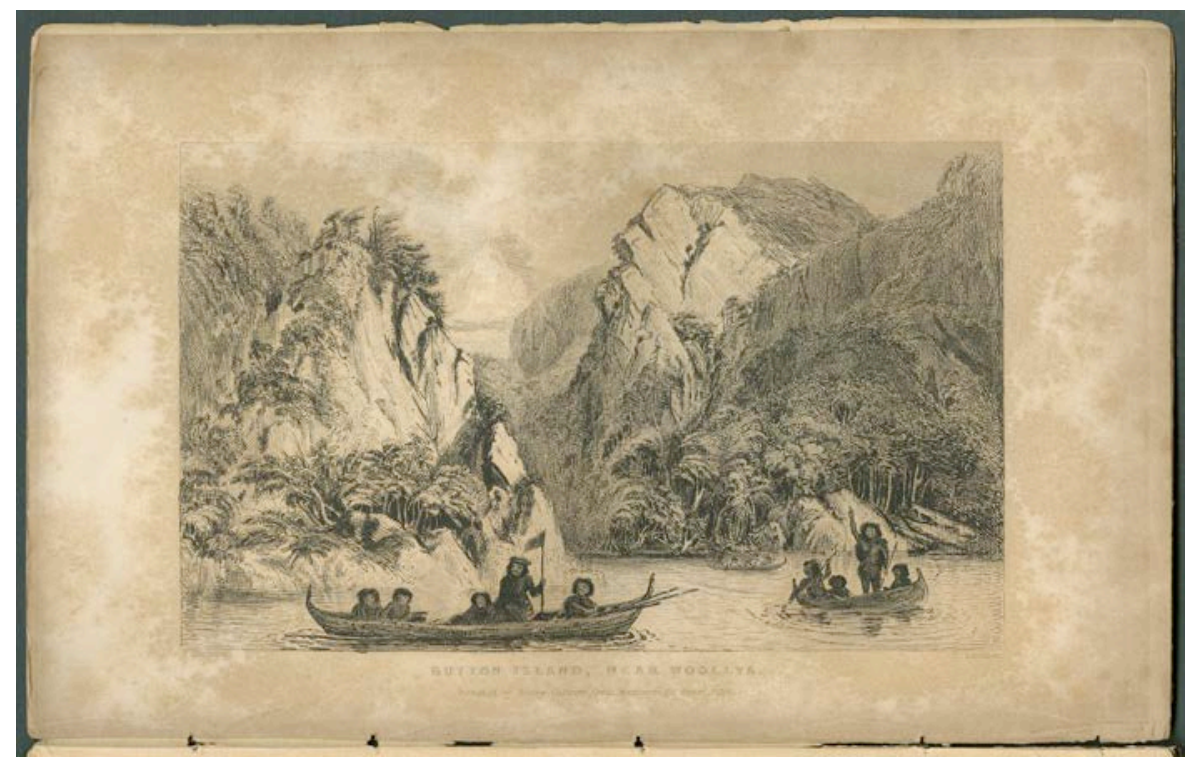

Fig. 8. Conrad Martens, Portrait Cove, Beagle Channel, PAF 6242. (C) National Maritime Museum, Greenwich.

más liviana y en base a transparencias en los elementos del paisaje, en especial en el follaje, el cielo y la elevación de la derecha, donde incluso se advierten chorreaduras. Contrastando con estas pinceladas libres, el Beagle, igual que en otras pinturas, se recorta del fondo gracias a la nitidez de la ejecución. La tonalidad general es cálida, con una paleta de ocres y verdes, que apenas equilibran los azules muy claros del cielo. Llama la atención el margen izquierdo ocupado por esa vegetación grisácea y enmarañada que suscitó en Darwin la comparación desventajosa con la selva brasileña. Este ingrediente, poco usual en las imágenes de Martens, otorga a la acuarela cierto pintoresquismo debido a la mayor variedad de elementos que la integran.

En el entorno de "Portrait Cove", las distintas posiciones que asumen los indígenas -algunos aún están sentados dentro de la canoa, uno se ha levantado y los otros ya salieron de la embarcación- transmiten la sensación de una escena congelada en un instante, lo que se enfatiza por la actitud de estos "modelos", alertas a una "cámara" fuera de la imagen a la derecha. La mirada dirigida al espectador, rasgo recurrente de las acuarelas fueguinas de Martens que es retomado por los grabados, se abre a varias interpretaciones. Podemos ver en ella una simple traslación icónica de los repetidos relatos de Narrative... acerca de la ansiedad de los nativos por entrar en contacto con los expedicionarios. Yendo un poco más allá, la "pose" respondería a una concepción del paisaje donde las figuras, igual que las rocas o las plantas, son parte de un todo dado a la mirada del viajero. Esta integración figura-paisaje no es ajena a la formación de Martens. De hecho, los contemporáneos de Fielding señalaban en sus obras un estatismo que hacía percibir de manera indiferenciada los elementos que las componían, mientras que reconocían en algunos de sus colegas el don del movimiento ${ }^{76}$. En el contexto de una expedición al fin del mundo, los indígenas, de un modo metonímico, estarían representando, con su actitud abierta hacia la observación externa, una disponibilidad para el estudio y la explotación que los europeos atribuían a los espacios explorados. Finalmente, y ya hilando fino, la mirada fuera del cuadro mostraría cuán dependientes eran los indígenas del examen y juicio del blanco para existir en imagen. Con sus rostros escamoteados o borrosos, los fueguinos de Martens que los grabadores trasladan a las láminas son un pueblo 
subexpuesto $^{77}$, que accede a la representación icónica al costo de ser considerado naturaleza.

La función que cumplen recuerda hasta cierto punto la de los figurantes del teatro y el cine, que para Georges Didi-Huberman son un accesorio de humanidad, un simple decorado humano $^{78}$, con la salvedad de que en nuestro caso no resultan innecesarios a la peripecia sino todo lo contrario. En forma inversa al paisaje de la pampa en el ciclo del malón que realizó Mauricio Rugendas a mediados del siglo $\mathrm{XIX}^{79}$, el cual resulta casi inexistente $y$, paradójicamente, a la vez es condición necesaria de lo que allí acontece, los fueguinos en las acuarelas de Martens son complementos imprescindibles del paisaje. Así sucede con los que saludan al espectador en el grabado "Button Island, near Woolya" (Fig. 9), elaborado por Landseer a partir de una acuarela del cuaderno $\mathrm{IV}^{80}$. En ésta aparecen dos macizos de rocas que hacen impracticable la costa, donde una mata de ramas y hojas deja entrever la vegetación entangled, que el pintor resuelve con trazos y manchas verde azuladas.

Otros ejemplos de complementariedad paisaje-figuras son las vistas ambientadas en el mar, como aquella (Fig. 10) que sirvió de base a la lámina "North East Side of Wollaston Island...". Los nombres, tanto de los originales como de sus derivaciones grabadas, avalan el sentido que vengo comentando, en la medida en que indican casi sin excepción los sitios y no a sus habitantes. Tanto en la acuarela como en la estampa, los personajes asomados desde la canoa son muy sintéticos, apenas unas cabezas con insinuación de torso, las cuales no hacen más que reforzar la idea de soledad de los canales, solo frecuentados por esos seres miserables. Este clima es aún más acentuado en la pintura a causa de la paleta que aplicó Martens, dominada por el gris y los azules para las montañas y el agua, mientras que el cielo, amenazado de nubarrones, presenta en su centro una luz intensa de coloración ocre-rosada. Rompen la oscuridad del conjunto una gaviota y un humo

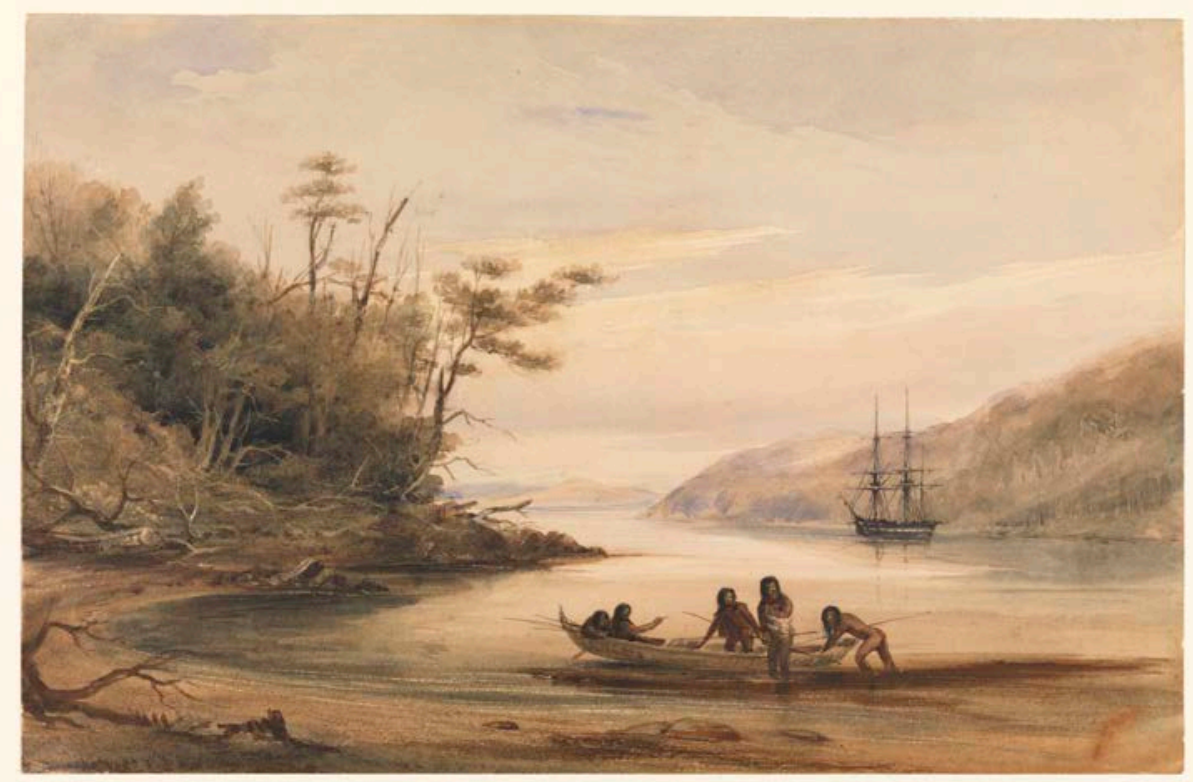

Fig. 9. Conrad Martens-Thomas Landseer, Button Island, near Woolya, Narrative tomo II. Cortesía Biblioteca Nacional de la República Argentina.

77 Didi-Huberman, 2014 [2012]. Pueblos expuestos. Pueblos figurantes. Manantial, Buenos Aires, p. 14.

78 Ibidem, p. 154.

79 Penhos, 2008. Modelos globales frente a espacios locales: tensiones en la obra de dos artistas europeos en la Argentina del siglo XIX. Studi Latinoamericani, 4, pp. 139-164, pp. 145-146.

80 Organ, 1996, op. cit., cat. 189. 


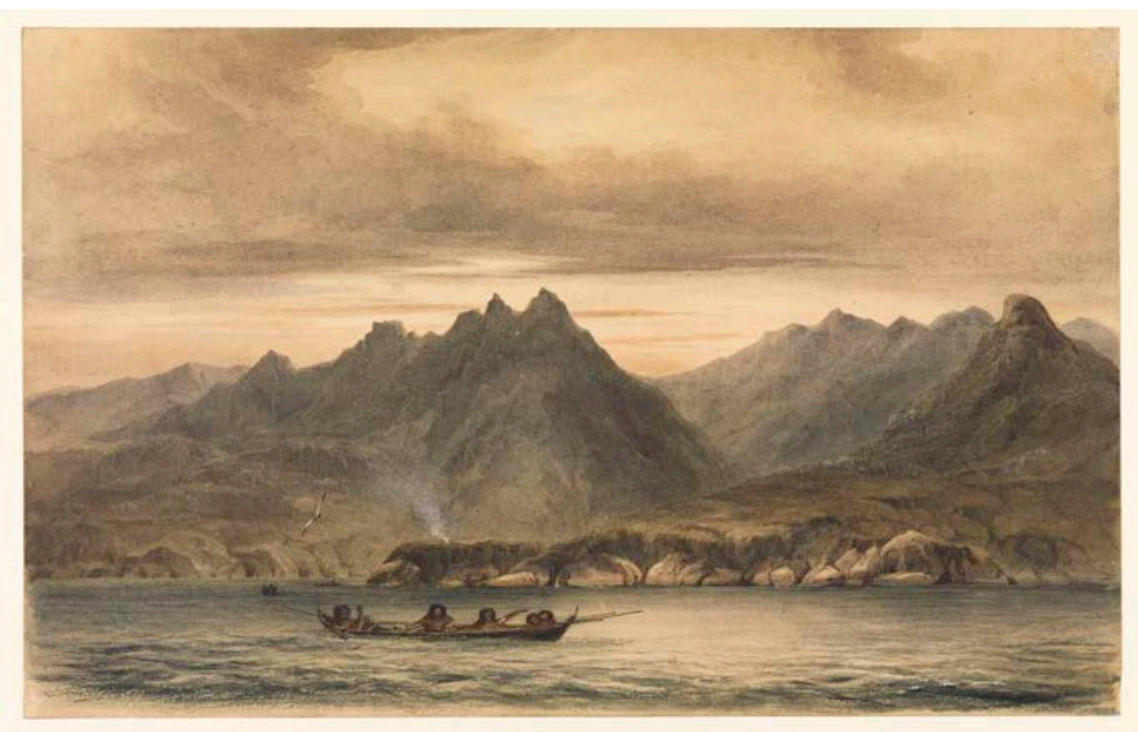

Fig. 10. North East Side of Wollaston Island near Cape Horn, PAF 6241.

(C) National Maritime Museum, Greenwich.

sutil que sale de la canoa. Muy atrás, dos simples manchas hacen las veces de embarcaciones que se acercan. Como parergon de los paisajes, las figuras resultan un agregado que coopera con el sentido total de la imagen ${ }^{81}$.

Los fueguinos de las imágenes beagleanas no habitan el espacio representado, porque sus viviendas son precarias y transitorias; no extraen de él sus alimentos, ya que nunca aparecen pescando o cazando; no son capaces de disfrutar con la contemplación de aquello que los rodea; y no viajan, sino que pasan sin apenas dejar huella, en forma semejante a sus canoas sobre el agua. Así, se diferencian de las figuras en los paisajes de la tradición del norte de Europa: pastores, viandantes y parejas de paseo que se detienen a mirar el entorno; ellos, como las casas, los puentecillos, las parcelas cultivadas $y$ las ruinas, expresan un espacio fuertemente marcado por la presencia humana. En cambio, las representaciones fueguinas de Martens, en consonancia con las que sus compañeros de viaje dejaron por escrito, muestran espacios enteramente naturales, y reservan la humanidad para una mirada externa y opuesta a ellos.

81 Según Jacques Derrida, el parergon es algo que se agrega al tema principal de la obra (ergon), como un accesorio que toca y coopera, desde un cierto afuera. Ver Derrida,

\section{FIGURAS ESQUIVAS}

Que Martens no manifestó una atención particular a los indígenas es algo que puede comprobarse en sus palabras, o más bien en sus pocas palabras. Lejos de la enjundia entre científica y filantrópica que animó la prosa de Fitz Roy, y sin que se haya suscitado en él una curiosidad semejante a la que inspiró algunos párrafos de Darwin, el artista apenas les dedica unas líneas en su diario. Sin embargo, y seguramente por considerarlo parte de su trabajo a bordo, realizó varios estudios de patagones y fueguinos y algunas composiciones elaboradas que los incluyen, como en el caso de la acuarela que sirvió de base para una lámina de Narrative... ${ }^{82}$. Una página del cuaderno III fechada en enero de 1834 muestra dos figuras de medio cuerpo, como emergiendo de la tierra o sumergidas en el agua. Uno podría pensar que es un estudio para una representación de fueguinos dentro de una canoa, si no fuese porque la leyenda incluye la palabra patagonians y la locación bahía San Gregorio, además de que contamos con la clara referencia a esa jornada

2001. La verdad en pintura. Paidós, Barcelona, p. 65.

82 Por ejemplo, Organ, 1996, op. cit., cat. 122. 
en el diario del artista. Martens expresa tanto la satisfacción que le dio observar a tres tehuelches que subieron al Beagle, como la sospecha de que la mansedumbre $y$ humildad de sus semblantes eran más producto del cálculo que demostración de genuinos rasgos de carácter ${ }^{83}$. Si prestamos atención, la acuarela presenta el desdoblamiento de un único personaje que es estudiado de frente y perfil, un tipo de imagen que surge en otros ejemplos de Narrative... en relación con la intención clasificatoria y los estudios de fisiognomía y frenología de Fitz Roy aplicados a los indígenas ${ }^{84}$. No deja de ser interesante que, en el párrafo de su diario, Martens hable de un necesario estudio de esa cabeza para despejar dudas acerca del carácter de los patagones, comentario que indica una sintonía con el comandante respecto de esas teorías. Sin embargo, aun en las imágenes de estudio, las facciones de tehuelches y fueguinos son moderadas, sin alcanzar el detalle al que lo habría llevado una mirada etnográfica como la de Earle o un decidido interés por la fisiognomía. Sus figuras, de anatomías someras y proporciones equilibradas, tienen poca vitalidad, y cuando se trata de retratos, están elaborados en base a cánones de belleza occidentales difícilmente aplicables a los habitantes del sur de la Patagonia.

Respecto de esta cuestión, debieron ser elocuentes los dibujos que Martens le habría presentado a Fitz Roy en la entrevista que tuvo lugar en Montevideo en octubre de 1833, cuando el comandante debía evaluar sus condiciones para sustituir a Earle. Días después de este encuentro, Fitz Roy escribía a Darwin, quien se hallaba en los alrededores de Buenos Aires: Martens es un hombre bien formado. Sus paisajes son realmente buenos [...], aunque tal vez en figuras no puede igualar a Earle. Es muy trabajador, y caballero en sus hábitos ${ }^{85}$. Fitz Roy reproduce en esta carta el comentario entusiasta de Martens sobre sus expectativas similares a las de muchos artistas viajeros: alcanzar el pináculo de los Andes o esbozar un glaciar fueguino ${ }^{86}$, es decir, poner a prueba su arte en geografías exóticas.

\footnotetext{
83 Organ, 1994, op. cit., p. 22.

84 Ver Penhos, 2018, op. cit., cap. VI.

85 Citado en Keynes, 1979, op. cit., p. 159.

86 Ibidem.
}

\section{LO OBSERVADO Y LO APRENDIDO}

Como vamos comprobando, Martens no consideró a los seres humanos materia de representación más que como un elemento integrado al paisaje. Hay que volver entonces al entrenamiento del artista, que junto con la escasa empatía que le suscitaron los habitantes del sur del Sur, dio orientación a su obra en el tramo que estamos estudiando.

Nada nos indica que Martens haya frecuentado la obra de Humboldt antes de salir de Inglaterra. Greppi plantea que, gracias a su amistad con Darwin, el artista pudo leer al sabio $e$ imbuirse de sus ideas acerca de la pintura de paisaje como vía para dar a conocer la fisonomía de la naturaleza ${ }^{87}$. Además, el encuentro en Valparaíso con un colega directamente involucrado con el programa estético humboldtiano, el ya mencionado Rugendas, lo habría afirmado en una línea de trabajo que, según Keynes, perfeccionó más tarde en su etapa australiana ${ }^{88}$. No obstante, teniendo en cuenta que ni siquiera la relación entre los pintores coloniales australianos y Humboldt está debidamente documentada ${ }^{89}$, esta referencia no resulta suficiente para explicar las elecciones plásticas de Martens durante el viaje. La predilección por paisajes solitarios o habitados por personajes empequeñecidos y estáticos parece provenir del círculo de acuarelistas al que pertenecía Fielding, cuyas ideas de lo sublime y de lo pintoresco estaban alimentadas por la lectura directa de Gilpin, Edmund Burke, Joseph Addison y otros autores dieciochescos más que por la obra de Humboldt. También a las enseñanzas del maestro, y a la frecuentación de Turner, hay que atribuir el interés de Martens por los efectos climáticos, aunque sin duda la experiencia junto con Fitz Roy -quien con el tiempo se convirtió en un verdadero experto en meteorología- contribuyó a incrementar su solvencia en la captación de variantes atmosféricas. Recordemos los dibujos de nubes del comandante que se incluyeron en el Apéndice al volumen II de Narrative... Tal vez fueran uno de los insumos que Martens tuvo en mente en Australia a la hora

87 Greppi, 2005, op. cit., p. 31.

88 Keynes, 1979, op. cit., p. 2.

89 Bonyhady, 1991, op. cit., p. 65. 
de plasmar los diferentes tipos de nubes que -dice Bonyhady- fueron su preocupación principal ${ }^{90}$.

La marca de lo aprendido es muy evidente en algunas de las imágenes beagleanas de Martens. Basta evocar "Lake scene" o "Loch Earn with Ben Vorlich" de Fielding ${ }^{91}$ para darnos una idea de las similitudes en el encuadre, en la distribución y proporción relativa de los elementos, en el uso de planos de colores cálidos y fríos, y en la preferencia por una luminosidad radiante en los fondos. La suavización de los contrastes, por efecto de la técnica pero también de la luz que envuelve el conjunto, es otro rasgo compartido por los acuarelistas británicos que Martens vuelca en su producción patagónica y fueguina.

Otras imágenes que pudieron incidir en la producción de esta etapa del artista son las láminas de las ediciones de Cook, Weddell y otros viajeros, que formaban parte de la biblioteca del Beagle. La minimización de la presencia humana frente a la vastedad de la naturaleza, las naves rodeadas de bloques de hielo y las montañas entre nubes están presentes en algunos de los grabados para los viajes de Cook derivados de dibujos de Hodges. También las parejas de fueguinos dibujadas por Hodges y por Sydney Parkinson que, llevadas a la estampa, resultaron más idealizadas que las originales, son posibles fuentes de la obra de Martens.

Todo esto no significa reducir la obra de Martens a una repetición de modelos y referencias previas. Tanto Smith como Greppi dan valor al papel de la experiencia directa de los artistas viajeros en la conformación del imaginario visual de los espacios extraeuropeos, al tomar en cuenta algunos ejemplos en los que aquella se impuso a los cánones heredados con especial fuerza ${ }^{92}$. En el caso de nuestro artista, afirma Organ que la variedad de paisajes pintorescos que encontró a lo largo del camino, entre ellos el desierto duro, amargamente frío, lluvioso y azotado por el viento de Tierra del Fuego [...], fue una poderosa influencia para é ${ }^{93}$. Por su parte, Mateo Martinic destaca el aporte de Martens como padre o

\footnotetext{
90 Ibidem, pp. 92-93.

91 Ambas en la colección de la Tate Gallery, Londres.

92 Smith, 1985 [1960], op. cit., p. 65; Greppi, 2005, op. cit., pp. 13-14.

93 Organ, 1993, op. cit., p. 16.

94 Martinic, 2007. Noticias sobre los inicios de la pintura
}

fundador de la pintura realista en Magallanes ${ }^{94}$. No hay duda de que tanto la observación como las vivencias durante el itinerario sudamericano nutrieron la producción del artista y se combinaron con el aprendizaje previo para dar cuenta de espacios totalmente ajenos a sus parámetros perceptivos y a las pautas estéticas de su cultura. Como hemos visto, la exploración del río Santa Cruz generó una interesante elaboración plástica del carácter despojado del espacio circundante. En los paisajes fueguinos se evidencia su esfuerzo por llevar a la imagen el tipo de vegetación seca de las orillas, la composición de los suelos y las rocas, el aspecto de las lejanías montañosas y, en particular, la atmósfera gris y la forma alargada de las nubes, estas últimas, dos características permanentemente anotadas en su diario y en los de sus compañeros del Beagle.

La confrontación de lo observado y estudiado in situ por una parte, con lo ya sabido y visto por otra, produjo tensiones y desajustes en la mayor parte de las imágenes de Martens de esta etapa, que incluso Darwin señaló. El joven naturalista, que había compartido con Martens un intenso año en las regiones australes, apreció sus obras al punto de comprarle dos acuarelas cuando se reencontraron en Sydney: una vista del río Santa Cruz y otra del Beagle en el canal homónimo. Pero ello no obstó para que comentase en una carta el abismo inevitable que veía entre las abrumadoras vivencias de los viajeros en un mundo completamente extraño y las convenciones estilísticas de los paisajistas ${ }^{95}$. Las imágenes, en las que los expedicionarios depositaban la esperanza de dar cuenta de aquello que se resistía a las palabras, también tenían sus limitaciones.

Falta aún ahondar más en la formación de Conrad Martens para identificar de manera más completa la deuda de éste con su maestro y otros referentes en cuanto a recursos compositivos y técnicos. En particular el círculo de los acuarelistas puede brindar muchas pautas en ese sentido, y también abrir la posibilidad de comparar

realista en Magallanes (1834-1940), Magallania, 35(1), pp. 5-32, p. 8.

95 Donald, 2009. Introduction. En Donald y Munro. Endless forms. Charles Darwin and the Visual Arts. Fitzwilliam Museum, Cambridge/Yale Center for British Art/ Yale University Press, New Haven \& London, p. 6. 
obras de artistas que, a partir de una educación artística semejante a la de Martens, fueron ajenos a la experiencia del viaje. Además, con el fin de explorar ampliamente la tensión entre lo sabido y lo observado, sería necesario un estudio integral de la obra del artista durante el viaje, teniendo en cuenta las imágenes que realizó en otros puntos del itinerario. Sin embargo, por medio del análisis llevado a cabo en este artículo creemos haber avanzado en la demostración de la intervención activa y decisiva del aprendizaje y entrenamiento artísticos de Martens en su percepción y concepción de los espacios patagónicos y fueguinos y en la realización de una parte sustancial de su producción durante la segunda etapa del viaje del Beagle. La confrontación de fuentes textuales, en especial el diario del artista, permitió identificar nociones aplicadas a esos espacios que eran parte de la cultura visual europea de la época, así como enfoques peculiares y propios del ámbito en el que el artista se formó en Londres. Todo ello parece haber participado, en una tensión colaborativa con la observación y la experiencia directa, y en confluencia con las representaciones de otros miembros de la expedición, en la invención de una Tierra del Fuego que poco a poco lograba ser comprendida por medio de las categorías de la ciencia y el arte occidentales.

\section{BIBLIOGRAFÍA}

Bonyhady, T. (1991). Images in Opposition: Australian Landscape Painting, 1801-1890. Melbourne: Oxford University Press.

Browne, J. (1995). Charles Darwin. Voyaging. Princeton: Princeton University Press.

Browne, J. (2007). La historia de El Origen de las Especies de Charles Darwin. Barcelona: Debate.

Burkhardt, F. (Ed.) (1996). The Beagle letters. Cambridge: Cambridge University Press.

Chapman, A. (2009). Darwin en Tierra del Fuego. Buenos Aires: Emecé

De Certeau, M. (2007). La invención de lo cotidiano. 1. Artes del hacer. México: Universidad Iberoamericana.

De Vries-Evans, S. (1993). Conrad Martens on the Beagle in Australia. Brisbane: Pandanus Press.

Derrida, J. (2001). La verdad en pintura. Barcelona: Paidós.

Didi-Huberman, G. (2014 [2012]). Pueblos expuestos. Pueblos figurantes. Buenos Aires: Manantial.
Donald, D. (2009). Introduction. En D. Donald \& J. Munro (Eds.), Endless forms. Charles Darwin and the Visual Arts. New Haven \& London: Fitzwilliam Museum, Cambridge/Yale Center for British Art/Yale University Press.

Gladstone Steele, J. (1978). Conrad Martens in Queensland: the frontier travels of a colonial artist. Brisbane: University of Queensland Press.

Greppi, C. (2005). 'On the Spot': Traveling Artists and the Iconographic Inventory of the World 1769-1859. En Driver, F. y Martins, L. (Eds.), Tropical Visions in the Age of Empire (pp. 23-42). Chicago: University of Chicago Press.

Hewison, R. (2000). Ruskin, Turner and the Pre-Raphaelites. Londres: Tate Gallery.

Hole, G. (Ed.) (1922-1923). Masters of Water-Colour Painting. Londres: The Studio Ltd.

Keynes, R. D. (Ed.) (1979). The Beagle Record. Selections from the original pictorial records and writen accounts of the voyage of H. M. S. Beagle. Cambridge-LondresNueva York-Melbourne: Cambridge University Press.

Martinic, M. (1982). Algunos dibujos inéditos de Conrad Martens en la Patagonia. Anales del Instituto de la Patagonia, 13, 51-57.

Martinic, M. (2007). Noticias sobre los inicios de la pintura realista en Magallanes (1834-1940), Magallania, 35(1), 5-32.

Organ, M. K. (1993). Conrad Martens and the Picturesque: Precursor to Australian Impressionism, 5-25 www.uow. edu.au/ morgan/graphics/cmpicturesque.pdf [acceso: $12 / 6 / 2012]$.

Organ, M. K. (1994). Conrad Martens: Journal of a Voyage from England to Australia aboard HMS Beagle and HMS Hyacinth 1833-35. Wollongong: State Library of New South Wales.

Organ, M. K. (1996). Conrad Martens' Beagle Pictures. General Catalogue of the Drawings, Watercolours \& Oils executed by Conrad Martens in association with his voyages to South America \& the Pacific Islands whilst Artist with the Beagle Expedition on board vessels such as HMS Hyacinth, May 1833-9 February 1835, http://works.bepress.com/morgan/41 [acceso: $10 / 4 / 2013]$.

Ottley, H. (1866). A Biographical and Critical Dictionary of Recent and Living Painters and Engravers. Forming a Supplement of Bryan's Dictionary of Painters and Engravers as edited by George Stanley. Londres: Bohm.

Penhos, M. (2005). Ver, conocer, dominar. Imágenes de 
Sudamérica a fines del siglo XVIII. Buenos Aires: Siglo XXI editores.

Penhos, M. (2007). De la exactitud y la incertidumbre del conocimiento. Malaspina en Patagonia (1789). En Salvatore, R. (Coord.). Los lugares del saber. Contextos locales y redes transnacionales en la formación del conocimiento moderno. Buenos Aires: Beatriz Viterbo Editora.

Penhos, M. (2008). Modelos globales frente a espacios locales: tensiones en la obra de dos artistas europeos en la Argentina del siglo XIX. Studi Latinoamericani, 4, 139-164,

Penhos, M. (2016). Las fotografías del Álbum de Encina, Moreno y Cía. (1883) y la construcción de la Patagonia como espacio geográfico y paisaje. Huellas, búsquedas en Arte y Diseño, 9, 65-80.

Penhos, M., \& Baliña, F. X. (2018). Y la nave va... Muchas historias para una historia, y algunas imágenes también. En Penhos, M., Paisaje con figuras. La invención de Tierra del Fuego a bordo del Beagle (1826-1836). Buenos Aires: Ampersand.

Smith, B. (1985 [1960]). European Vision and South Pacific,
1768-1850. New Haven: Yale University Press.

Smith, B., \& Joppien, R. (1985). The art of Captain Cook's voyages. Melbourne: Yale University Press.

Van Meurs Valderrama, M. (2014). Conrad Martens en Chiloé, 1834. Ancud: Ediciones Museo Regional de AncudDirección de Bibliotecas, Archivos y Museos.

\section{FUENTES}

Conrad Martens, Acuarelas, PAF 6227-6242, National Maritime Museum (Greenwich).

Conrad Martens, Sketchbooks I y III, Ms. Add. 7984, Cambridge University Library.

Chancellor, G., \& Van Wyhe, J. (2002). Darwin's Beagle field notebooks (1831-1836). En Van Wyhe, J. (Ed.), The Complete Work of Charles Darwin Online, http:// darwin-online.org.uk/ [acceso: 15/11/2016].

Earle, A. (1832). A Narrative of a Nine Months Residence in New Zealand in 1827. Londres: Longman \& Cia.

Narrative of the Surveying Voyages of his Majesty's ships Adventure and Beagle... in three volumes, London, Henry Colburn, 1839. 